\title{
OVERZICHT VAN DE HOOGERE BURGERSCHOLEN EN BURGERSCHOLEN BIJ HET EINDE VAN 1868.
}

\author{
Ook naar aanleiding van het bug de behandeling der Staatsbegrooting voor \\ 1869 in de Staten-Generaal over middelbaar onderwijs gesprokene.
}

\section{§4. Het onderwys.}

Indien $\mathrm{k}$ thans weder, even als het vorig jaar, een overzicht wilde geven van de programma's van de verschillende in werking zijnde hoogere burgerscholen, zou ik noodzakelyk in herhaling moeten vervallen van veel, wat toen reeds is medegedeeld. Daar er in de regeling der bestaande scholen geen verandering van eenig belang is gekomen en de programma's der nueuw opgerichte grootendeels met die der vroeger geopende overeenkomen, zou zoodanig overzicht niets nieuws kunnen opleveren voor hen, die van mijn vorig opstel kennis genomen hebben; $z 1 j$, met we dit nuet het geral is, meen $\mathrm{lk}$ daarheen te mogen verwijzen.

Daar ik evenwel in de volgende bladzıjden eenıge beschouwıngen over den omvang en de richting van het onderwljs aan de hoogere burgerscholen wensch mede te deelen, bepaaldelijk ook naar aanlelding van hetgeen daarover in de Staten-Generaal is gesproken, zoo komt het mij niet ondoelmatig voor hier een dergelijk normaal programma voor eene school van vifjarigen cursus mede te deelen, als $1 \mathrm{k}$ vroeger heb opgenomen. De letters, voor de namen der leervakken geplaatst, zijn die van art. 17 der Wet. 


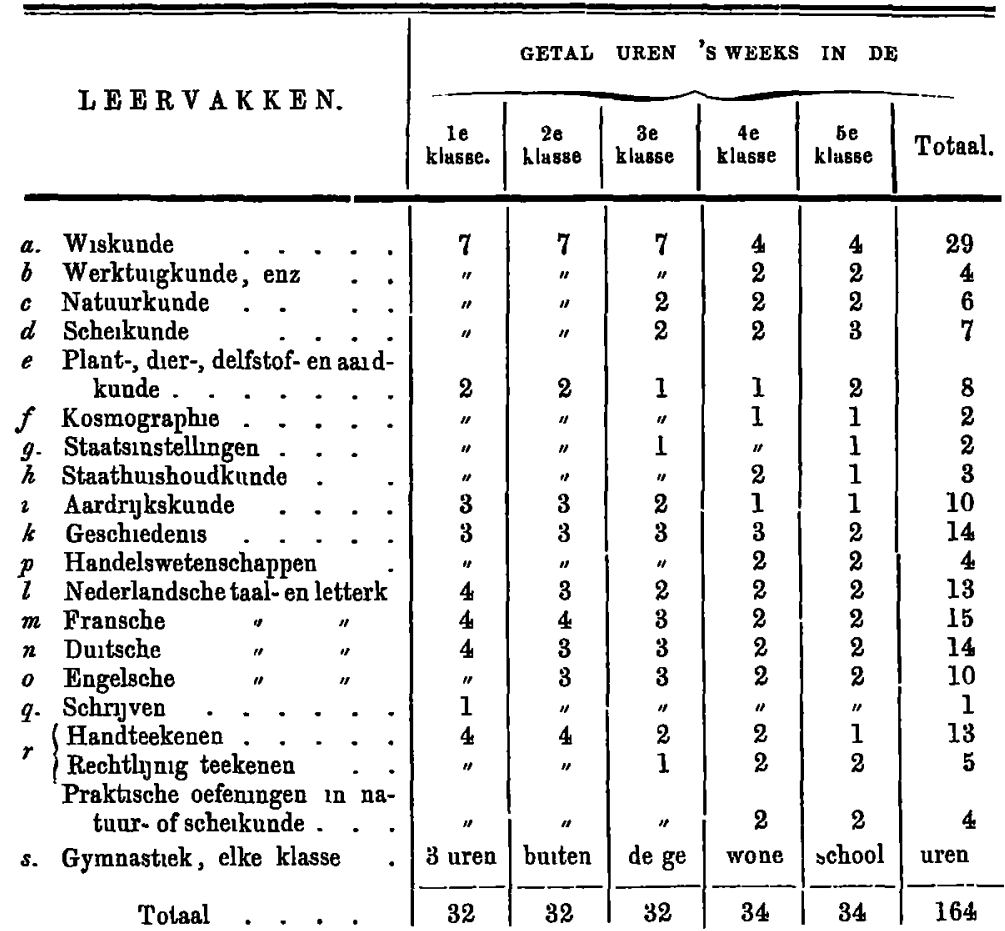

Voor een paar vakken wijkt dit programma een weinig van het vroegere af. $B_{1 j}$ nader inzien acht $1 k$ het betor, dat in alle klassen, dus ook in de $3_{e}$, onderwijs in natuurlijke historie wordt gegeven, zonder dat evenwel het totail daarvoor bestemde getal uren wijziging behoeft te ondergaan; $1 \mathrm{k}$ heb duarom één uur van de $4 \mathrm{e}$ nar de $3 \mathrm{e}$ klasse overgebracht. On nogtans het getal wekelijksche lesuren, met uitzondering van de twee roor praktısche oefeningen in natuur- of schelkunde bestemde uren, voor alle klassen op 32 te houden, heb ik het getal uren voor de geschiedenis in de 4e klasse met één vermeerderd en dat vour rechtlunig teekenen in de $3 e$ mot één verminderd. Meer ondervinding en nadere gedachtewisseling hebben mu het wenscheljjke van deze verschillende wijzigingen doen inzien (*).

Verdeelt men de vakken in eenige hoofdgroepen, dan verkrijgt men de volgende totalen:

(*) Ik herhaal hier de opmerking, due ik reeds het vorig jaal maakte, dat dit programma geen olhcieel karakter heeft, maar slechts mujn eigen gevoelen uitdrukt Neemt men het gemiddelde van alle bestaande, dan komt men evenwel nagenocy tot dezelfde uitkomst. 
A Wis en werktuigknnde (vak $a$ en $b$ vau art. 17 der Wet), 33 uren 's weeks;

B. Natuurkundige welenschappen, namelijk natuurkunde, scherkunde, natuurlijke bıstorie en kosmographie ( $v a k c, d, e$ en $f$ ), 23 uren 's weeks ;

C. Staats-, handels- en geschiedkundige wetenschappen, namelijk kennis der staatsinrichting, staathusshoudkunde on statistiek, aardrijkskunde, geschredenis en handelswetenschappen (vak $g, k$, $i, k$ en $p$ ), 33 uren 's weeks;

D. Taal- en letterkunde, namelijk Nederlandsche, Fransche, Duitsche en Engelsche taal en letterkunde (vak $l, m, n$ en $o$ ), 52 uren 's weeks;

E. Teekenen en schryven (

F Praktische oefeningen in natuur-en scheikunde, 4 uren's weeks;

G. Gymnastische offeningen ( $\mathrm{vak} s$ ), voor iederen leerling 3 uren 's weeks buitén de gewone schooluren

Toen in het Voorloopig Verslag van de Tweede Kamer over het Ve Hoofdstuk der Staatsbegrooting eene opmerking werd gemaakt over de eenzydige ruchting van het onderwijs, heeft de Minister in zijne Memorie van Beautwoording zich op de bestaande programma's ter bestruding van dat verwijt beroepen en doen uitkomen, dat $v a n$ den tijd, gedurende welken aan scholen van vijfjarıgen cursus onderwijs wordt gegeven, in ronde cyfers een derde gedeelte besteed wordt aun wis- en natuurkundige wetenschappen, een derde gedeeltc aan studie van taal en letterkunde, cen vijfde aan staats-, handels- en geschiedkundige wctenschappen en de overıge tijd aan teekenen en schrijren. Gymnastische oefenıngen, die alleen plaats hebben met het doel om uitspanning te geven, worden hier onder de eigenlijke leervakken niet medegeteld. Aan scholen van dezen aard wordt dus nagenoeg twee derde gedeelten van den tujd besteed aan andere dan wis- on natuurkundige wetenschappen, aan de scholen van driejarigen cursus, wier programma nagenoeg overeenkomt met dat van de drie laagste klassen eener volledige inrichtıng, wordt niet meer dan een vierde van den schooltijd aan wis- en natuurkunde gewijd.

Mocht het, na deze verklaringen van den Minister, verwonderung baren, dat nogtans verscheidene leden, zoowel in de Eerste als in de Tweede Kamer der Staten-Generaal, andermaal op die zoogenaamde eenzijdige richting van het onderwijs aan de hoogere burgerscholen terugkwamen, niet minder had men reden zich to verwonderen ovor de heftige beschuldigingen, die tegen dat onder- 
wijs in 't algemeen werden urtgebracht. De heer Gefken „duızelde „van al die leervakken, al die geleerdheıd en verwachtte niet reel „van het geslacht, dat in die instellingen van middelbaar onderwijs "wordt opgeleid." Volgens hem zljn „de hoogere burgerscholen op „eene helling, neêrdalende tot het materialısme," en moest gewezen worden op het $\epsilon$ rkende ongeloof van vele leeraren." Daaraan was volgens hem de eenzijdige ruchting, de verkeerde geest, warin het onderwijs gegeven wordt, vooral in de wis- en natuurkunde, toe te schrijven. De heer van Wassenaar van Catwijck toonde zich bevreesd voor de verkeerde richting, die de tot leeraren angestelde moderne predikanten aan het onderwijs zullen geven. Toen de Minister had opgemerkt, dat er onder de 400 leeraren niet meer dan elf $\left(^{*}\right)$ waren, die in dit geval verkeerden, vroeg de heer van Nispen van Sevenaer, „of het dan niet bekend is, dat het niet die elf „alleen zijn, maar een veel grooter getal, waarvan men weet, dat „zij dergelijke denkbeelden koesteren, en of het niet genoeg bekend „is, dat er eene richting in dat onderwijs is, die staat tegenover den "geloovigen Christen ?" Volgeus hem was het eene "genoeg bekonde "zaak, waaromtrent bij niemand in het geheele land eenige twufel "kan bestaan." De heer J. K. van Goltstein meende, „dat het "gehalte van het middelbaar onderwijs wel iets te wenschen over"laat en dat die opmerking door bevoegde deskundigen wordt "gedeeld. De jeugdige hersens kunnen den vloed van kundigheden, "waardoor zij overstelpt worden, zich niet behoorlyk eigen maken "en loopen gevaar naar die soort van vogelen te gelijken, die de "geschiktheid bezitten om de klanken die zij hooren op te vangen „en terug te geven, zonder den zin en de beteekenis daarvan te „beseffen."

In de Eerste Kamer was het niet beter gesteld; daar waren het vooral de heeren van Nispen van Pannerden, Hartsen en Cremers, die tegen het onderwijs aan de hoogere burgerscholen bezwaren hadden. De eerste drukte de vrees unt, dat „het geloof der leerlingen „gevaar liep door de moderne onderwijzers;" de heer Hartsen was, "1n elgen boezem voor dat middelbaar onderwijs terug gedeinsd, om"dat hij vreesde, dat de materiele rigting er van op den weg kon "leiden tot het ontstaan van eene generatie zonder fantasie, zonder "enthusiasme en dus zonder nationalen zin." De heer Cremers ging nog een stap verder door te waarschuwen, "dat de docenten er

(*) In $\$ 3$ heb ik van twaalf meldung gemaakt. In December is er namelyk nog één aangesteld. 
„zich toch geen genoegen uit zouden scheppen om proseliten to "maken."

Dat het niet aan tegenspraak ontbrak behoef ik wel niet te verzekeren. Het waren, behalve den Minister, in de Tweede Kamer vooral de heeren Dam, Jonckbloct, Lenting, Moens, de Bosch Kemper, in de Eerste de heeren Smit, Sassen en van Beeck Vollenhoven, die het middelbaar onderwijs trachtten $v$ rij te spreken van die beschuldigingen. Ik zal hier niet herhalen, wat door hen daartegen werd ingebracht, maar wensch alleen te doen uitkomen, dat de meesten er op wezen, dat or geen feiten waren aan den dag gebracht, die tot bewijs kouden strekken òf van de materialistische richting, ò van den strud tusschen het middelbaar onderwijs en het christelyk geloof, of ran de onderdrukking van den natronalen zin der jongelieden, óf eındelijk van de proselitenmakerij der docenten (*); dat de grieven dus alleen op ouderstellingen rustten en dat hetgeen als "algemeen bekend" genoemd werd, thans door velen voor 't eerst vernomen werd en nog bewezen moest wordon. Er moest dan ook erkend worden, dat die bewijzen net kunnen geleverd worden; zij zouden, zoo zeide men, alleen te vinden zijn in de verhalen en mededeelingen der leerlingen. De heer Saaymans Vader erkende zelfs, "dat, hoewel by hem de overtuiging geves„tigd was, dat die materialıstısche strekkıng in het middelbaar „onderwijs heerscht, hij geene bewljzen had om het te kunnen „staven. Alleen wilde hij vragen: „kenschetsen zich niet velen der ,jongelıeden, die van het middelbaar onderwijs gebruik maken, door „eene zekere meerdere moedwilhgheld? Onderscheiden zy zich door "voegzaamheld van gedragingen en eerbled voor het gezag? Hoort „men niet vaak redeneringen uit die jonge monden, waarover men „verbaasd staat? En matigeu zij zich niet meermalen een regt aan „om quaestien te beslissen, die zeker ver boven thun begrip zijn?" Die vraag van den heer Saaymans Vader is door niemand beantwoord, noch in bevestigenden, noch in ontkennenden zin; het antwoord is evenwel gemakkelyk te geven. Dat er onder de tal.

(*) Alleen de heel van Nispen van Sevenaer heeft in de Tweede Kamer van een feit gesproken (Byblad p 519), "er zon namelyk een schnftelyk bewns gevonden " zyjn vau de materiahstische stellingen die daar schulden, zeer ktundige en aangesiene " mannen, die door hunne betrekkngen geroepen waren om dat te keeren, hadden "geantwoord op de klagten daarover dat men daaraan niets kon doen, want dat "het wel bij de wet op het lager ondel wys, maar net by die op het middelbaar "was verboden" 'Waar en wanneer dit fert heeft plaats gehad, heeft de spreker echter nuet raedegedeeld 
rijke leerlingen del hoogere burgerscholen zun, op wier gedrag wel eens wat te zeggen valt, wie zal dat durven ontkennen? Wre zal de school, van welken aard ook, aanwijzen, waar nooit eene kleine ongeregeldheld heeft plaats gehad? Maar daarvan kan ik gerust de verzekering geven, dat de leerlngen der hoogere burger. scholen, wat orde en jiver aangaat, volstrekt niet behoeven achter te staan bij die van de gymnasiën of andere scholen. Levenslustighe1d en vrolijkheid zijn nog geen moedwil; ijver en belangstellıng in de vakken, waarin zij onderwijs ontvangen, nog geen aanmatiging 'en betweterij. Ik zou wenschen die vreesachtige tegenstanders, waurvan de meesten nooit in eene hoogere burgerschool zijn geweest, daar eens te mogen rondleiden, heo kennis te laten maken met de leerlingen der hoogere klassen, jongens van 16 tot 18 jaren, hen den geest te leeren kennen, die onder die jongelieden heerscht en hen te doen zien, welke warme belangstelling bij de meesten wordt aangetroffen voor hunne studiè, hoe hef zij hunne hoogere burgerschool hebben! Welk eene geheel andere opvatting zouden die heeren van ons middelbaar onderwijs krijgen! Ik twijfel geen oogenblik, of de heer Saaymans Vader zou het volkomen met mij eens zijn, dat, wauneer wij de orde en den geest, die thans nagenoeg in alle hoogere burgerscholen wordt waargenomen, vergelijken met den toestand van vele gymnasien en latijnsche scholen in den tijd toen $w y$ zelven daar onderwijs ontvingen, de uitkomst net 'ten gunste van het verleden zou wezen

Veel gewicht was vooral te hechten aan de verklaringen van enkele leden (de heeren Dam, Moens, Lenting un de Tweede Kamer, de heeren Smit en Sassen in de Eerste), die door hun lidmaatschap eener Commissie van Toezicht op het middelbaar onderwijs beter dan anderen in staat waren gesteld, den geest van het onderwijs van nabij te leeren kennen De Minıster zelf, zlch grondende op de ondervinding, te Haarlem en te Amsterdam opgedaan, en op de officieele rapporten ran de inspecteurs, die weder jaarlijks de verslagen van de Commissien van Toezicht ontvangen, constateerde dat ools hem van die verkeerde richting niets was gebleken. Men moest derhalve feiten 'aanbrengen, en wilde men dit niet in het openbaar, ook officieus zou hij er gaarne kennis van nemen en de zaak bëhandelen met al den ernst, dien zij verdiende. Maar behalve de bovenvermelde eenigszıns onbepaalde aanwijzing van den heer van Nispen van Sevenaer, bracht wiemaud sets te roorschija; zeer terecht werd van den anderen kant gewezen op de onmogelijkheid om thans reeds, nu nog geen enkele dier scholen meer dan vier jaren den dèn gang 
was, over de vruchten 'n den invloed op de verstandelijke en zedelijke ontwikkeling der jongelieden te oordeelen. Sommigen achtten een onderzoelk door de ambtenaren, in dit geval de inspecteurs, noodig $\left(^{*}\right)$; maar gelooven zij dan, dat de inspecteurs zoodanige herinnering, zoodanige opdracht noodig hebben om bij hun schoolbezoek na te gaan, of inderdaad het onderwijs voldoet aan do eischen der Wet? gelooven zij niet, dat, zoo wij in onze gesprekken met ingezetenen, vooral met ouders, in onze zamenkomsten met de Commissiën van Toezicht, klachten van welken aard ook vernemen, daarover door ons een onderzoek wordt ingesteld? Meenen zij niel, dat het juist het streven van de inspecteurs is om het onderwjis steeds te verbeteren en te doen beantwoorden aan de eischen, die in billjjkheid kunnen gesteld worden? Ik zou verscheidene voorbeelden kunnen bijbrengen, dat de inspecteur het initiatief heeft genomen, hetzij bij de plaatselijke commissie, hetzij bij het onderwijzend personeel, wanneer het bleek, dat of de orde of het onderwijs in sommige opzichten te wenschen overlieten; slechts zelden worden door hen bepaalde klachten afgewacht. Waar klachten tot mij kwamen, heb ik steeds, na zorgruldig onderzoek, den directeur of den betrokken leeraar daarover onderhouden; maar nog nimmer is tot mij eene klacht gekomen over de materialıstische strekling van het onderwijs. Werd al cens in enkele particuliere gesprekken de wrees uitgedrukt, dat er zoodauge richting in het onderwijs was of komen zoude, noolt heeft men mij er eenig bewijs van kunnen leveren, en' $\mathrm{k}$ moet dus wel aannemen, dat voor zoodanige klachten of vrees geen grond bestaat, tenzij men meer geloof wl hechten aan de onderstellingen en verbeeldingskracht van enkelen, die nummer eene hoogere burgersehool hebben gezien, dan aan de verklaringen van hen, wier plicht hen bijna dagelijks daar roept.

Het komt mij voor hier de geschukte plaats te zijn om te wijzen op eene zeer opmerkelijke zaak, namelijk dat de leden der Tweede en Eerste Kamer bij de laatste beg1ootıngsdiscussien, waarsehijnlijk zonder het zelven te weten, in dit opzicht nuets nieuws hebben medegedeeld, maar slechts herhauld hebben hetgeen voor meer dan dertzg jaren in westelyk Durtschland is gezegd en geschreven.

(*) De heer Cremers drukte in de Eerste Kamer zyne meening ut, dat zoodanig onderzoek weinig zou baten. Hy voegde er byj "by het onderwys in het algemeen "zollen, geloof $\mathbf{~ k}$, nuet ligt de superieuren de inferieuren willen blootstellen aan "aanmerkıngen." Waarlyk niet vlejend voor de unspecteurs, die by den aanvang huuner betrekkng den eed hebben afgelegd, dat zy die naar hehooren en getrouw sullen waarnemen. 
Nadat reeds in het begin van de $19^{\text {de }}$ eeuw op enkele platsen in Duitschland onder den nam van Realschnle of Holhere Burgerschule inrichtingen waren verrezen, in de eerste plaats bestemd voor de nijvere klasse; - nadat in 1822, onder den Director Spilleke de koninklijke reaalschool te Berlijn eene geheele reorganisatie had ondergaan, en men in Pruıssen de noodzakelijkheid eener algemeene regeling van dezen tak van het onderwijs had ingezien, - verscheen In 1832 eene eerste officieele instructie voor het onderwijs en de eindexamens aan de hoogere burgerscholen en reaalscholen in den Pruissischen Staat. Dientengevolge nam het getal dier inrichtingen in alle provincıën van Pruissen aanzienlijk toe; omstreeks denzelfden tijd onderging ook dit onderwijs in versoherdene andere duitsche landen, zooals Wurtemburg, Baden, Beijeren, Saksen, Hannover, eene aanmerkelijke untbreiding; maar tevens ontstond er ook een hevige tegenstand en strijd tegen de nieuwe instellingen. Vooral de voorstanders der gymnasien, of zooals het heette, van het „Humanısmus", trokken te velde tegen het „Realısmus” (*), dat evenwel onder de directeuren en leeraren der nieuwe inrichtingen krachtige en talentvolle verdedigers vond.

Onder de eersten moeten in de eerste plaats Gïnther, Thiersch en Heiland, onder de verdedigers der reaalscholen Nagel, Scheibert, Körner genoemd worden $(\dagger)$. Ik zal thans niet un bijzonderheden treden aangaande dieu strijd. De verwijten, die men tot de reaalscholen richtte, waren geheel dezelfde als die, welke men thans bjj ons verneemt. In de eerste plaats, dat de reaalscholen uitsluitend de materieele richtıng van onzen tijd vertegenwoordigén en

(*) De minder juste naam van Realschule, dien men in Dutschland vry algemeen an de neuwe scholen gaf, bracht ook niet weing by tot eene verkeerde opvatting (Men lese herover bıjv. Dr. Beneke's Biziehungs-und Unterrichtslehre, 3 e Auf , 2er Band., p 338) Wat men in Duitschland toen veelal realusme noemde, heet thans by ons materalzsme.

$(t)$ Een der eerste en heftigste bestiyders was Gunther in zyn geschrift "Die Realschule und der Matemahsmus, " kort daarop rolgde Thersch, in zunn werk “Ueber den gegenwartigen Zustand des offentlichen Unternchts in den Westlichen "Staaten von Deutschland, in Holland, Belgien und Frankueich " Later Dr. Heiland 1n zujn werk "Zux Fiage uber de Reform der Gymnasien. "Het uıtmuntende werk van Dr C. $H$ Nagel "Die Idee der Realschule, nach ihrer theoretischen Begrun"dung und praktischen Ausfithrung dargestellt" 1 bepaald tegen het bovenvermelde werk van Thersch gericht, het in 1851 verschenen werk van Korner. "Die "Bedeutung der Realschulen fur das moderne Kulturleben " dient vooral tot wederlegging van dat van Heiland $U_{1 t}$ beide werken, even als uit die van Scheibert, Kletke, Schacht en anderen, heb $1 k$, $1 k$ erken bet met dankbaarheid, veel geleerd, 
dientengevolge leiden tot een grof materialisme; voorts dat zij daardoor de ongodsdienstigheid en onzedelijkheid bevorderen en tot allerlei revolutionaire begrippen lesden; emdelijk dal in die scholen geen vaste grondslag voor het onderwijs gevonden wordt, zoo als de klassieke talen dien aan de gymnasien geven, en dat zij dus tot oppervlakkngheid en vroegrijpheid leiden. Mijne lezers zullen zeker nıet verlangen, dat $i k$ door eene bloemlezing uit de werken van de voorstanders van de duitsche hoogere burgerscholen (de bovengemelde van Nagel en Körner verdienen daaronder eene eerste plaats) hen bekend maak met de argumenten, waarmede de tegenstanders bestreden werden; misschien kom lk later nog wel eens uitvoeriger op dit onderwerp terug.

Er is evenwel onder de vele in de Staten-Generaal geuite be$\mathrm{zw}$ aren een enkel, dat $\mathrm{k}$ meen hier niet geheel opbeantwoord te mogen laten, daar het in de oogen van velen, die minder met de zaak bekepd zijn, een schijn van gegrounhe!ld voor zich heeft, namelijk de beweerde materialistische strekking van het onderwijs in de natuurkundige wetenschappen Dat het onderwijs daarin thans in de school niet kan gemist worden en rooral niet in de school, die bestemd is om aan den nijvereu stand en aan de kern der burgerij die kennıs en beschaving mede te deelen, die zij noodig hebben om zich in dien stand zelven verder te ontwikkelen, daarover is eigenlijk geen strijd; het wordt zelfs erkend door de bestrijders, zoo als de heeren Gefken, Saaymans Vader en van Nispen, en slechts schoorroetende waagde de heer Hartsen de vraag, „of het wel goed is dat onderwijs in al die rakken en nmet die positneve, maternele strekking aan het technisch onder$\eta$ wijs eigen, zoo algemeen te maken en te bevorderen door het zoo "goedkoop te stellen?" Men schijnt zich maar niet te kunnen onttrekken aan de vrees, dat behandeling van die zoogenaamde materieele wetenschappen tot materialısme, in zijne slechte beteekenis, moet leiden, en verliest geheel de groote paedagogische waarde van het natuurwetenschappelijk onderwijs uit het oog. Natuurbeschouwiug toch brengt den geest van het aanschouwelijke en zinnelijke onmiddellijk tot het bovenzinnelijke; zij vervult het gemoed met een gevoel van de verhevienherd van den Schepper; zij leert ons zoowel in het kleinste als in het grootste het verstand en de orde opmerkeu en bewonderen, waarmede alles in de natuur rondom ons geregeld is; zij leert ons vooral schijn van waarheid onderscheiden en onveranderlijke wetten erkennen, nergens wetteloosheid of willekeur. Moet niet de overtunging, dat in de vaststelling van die natuur- 
wetten de hoofdoorzaak te zoeken is van het behoud ran alles, wat hij om zich ziet, ook op de zedelijke ontwrkkeling van den waarnemer een hellzamen 1uvloed uitoefenen? Moet hij niet, wanneer hij eenigszins dieper doordringt in de vroeger voor hem gesloten geheimen der vatuur, en tot de innige overtuging komt, dat daarn nog zoo veel duister voor hem is en waurschyuljik steeds blijren zal, omdat het boveu het begrip van het menschelijk verstand gaat, - moet hl dan niet geheel doordrongen zijn van bewondering, en eer geleid worden tot ware godsvrucht en deemoed dan tot aanmatiging, tot materialısme en ongeloof? Is in zoodanige oefening van den geest niet een middel tot verstandsontwikkelıng gelegen, beter, edeler en rruchtbaarder dan eenıge andere tak van meuschelijke kennıs geven kan?

Maar, zeggen de tegenstanders, het is niet tegen de natuurwetenschappen op zich zelven dat wij bedenking hebben, maar tegen de eenzydige wijze, waarop zij onderwezen worden. De heer Gefken wilde ummers "dat zij in een anderen geest gedoceerd zouden "worden." In welken geest? Worden zij dan op eene verkeerde wijze onderwezen? "geschiedt dit," zooals de heer de Bosch Kemper zoo junst vroeg, "dan in zoodanige richting, dat men voor vergoding „der stof te vreezen heeft?" Doch niemand heeft eenı feit weten aan te brengen, waaruit dit kon blyken. Terecht merkte de heer van Beeck Vollenhoven in de Eerste Kamer op, dat "wanueer er onder „de leeraren zijn, die eene vrugeestige richting zijn toegedaan, zij "dat toch niet in het onderwijs kunnen brengen, of het moet blijken." En zelfs wanneer er al eeus een eukel gelsoleerd fett werd waargenomen, zooals dat, waarop de heer van Nıspen van Sevenaer scheen te doelen, zou men dan op groud daarvan mogen aannemen, dat het geheele muddelbaar onderwigs sich bevindt op eene helling neerdalende tot materialusme?

Ik geloof dat de beraadslagingen over het middelbaar onderwijs in de Staten-Generaal, hoezeer schijobaar zeer theoretisch en bespiegelend, in dit opzicht toch een praktisch resultaat hebben opgeleverd. Er is mijns unziens zonueklaar uit gebleken, dat de beschuldigingen, tegen zijne verkeerde strekking ingebracht, alleen haren oorsprong hebben ò in overgroote vreesachtigherd, ò in onbekendheid met de zaak, juist zooals voor dertig jaren in Duitschland het geval was, waar de strijd op nog veel grootere schaal is gevoerd. Daar 18 echter die strujd, voor zooveel mij bekend is, ten einde gebracht; de reaalscholen en hoogere burgerscholen hebben meer en meer de symputhe der bevolkung voor zich weten te winnen, 
zoo als blijkt uit het steeds toenemend getal der leerlingen $W_{i j}$ mogen dus in Nederland ook met vertrouwen de toekomst te gemoet zien. Aanvankelijk reeds is de bijval, dien het muddelbaar onder. wijs hier heeft gevonden, groot; hij overtreft zelfs de verwachting. Trachten allen, die tot dat onderwijs in betrekking staan, daaraan die verbeteringen aan te brengen, die het, even als iedere nieuwe zaak, nog zal behoeven; gaan de leeraren voort zich met hart en ziel te wijden aan de kostbare belangen, aan hunne zorgen toevertrouwd, blijven zij steeds het ware doel van hun onderwijs, ontwikkeling van het hart en het verstand hunner leerlingen, voor oogen houden, dan zal de tijd niet ver meer verwijderd zijn, dat Nederland in dat opzicht voor geen anderen beschaafden Staat behoeft onder to doen; dan zullen zelfs zij, die rroeger onder de bestrijders der hoogere burgerscholen behoorden, er waarschijnlijk volkomen vrede mede hebben, ja wellicht hunne ingenomenheld er mede aan den dag leggen.

5. De examens.

In een naauw verband met het onderwijs, dat aan de hoogere burgerscholen wordt gegeven, staan de examens, die aan die inrichtingen gehouden worden, zoowel de examens van hen, die tot die scholen toelating verlangen, als die, welke bij het einde van iederen cursus worden gehouden en waaruit moet blijken, of de leerlingen voldoende vorderingen hebben gemaakt om tot eene hoogere klasse bevorderd te worden, en de eindexamens, krachtens welke hun volgens het voorschrift der Wet een getuigschrift wordt uitgereikt. Ik laat hier een kort overzicht van die examens, voor zooveel het jaar 1868 betreft, volgen.

In de volgende tabel zijn de toelatings- en overgangsexamens opgenomen, wel te verstaan voor het volledig onderwijs. Van hen, die slechts enkele lessen bijwonen, wordt slechts op sommige plaatsen en onder bijzondere omstandigheden een examen gevorderd. 


\begin{tabular}{|c|c|c|c|c|c|c|c|}
\hline \multirow[b]{2}{*}{ SCHOLEN } & \multicolumn{3}{|c|}{$\begin{array}{l}\text { TOELAATINGS-EXAMENS. } \\
\text { Getal ran hen, die }\end{array}$} & \multicolumn{4}{|c|}{$\begin{array}{l}\text { OVERGANGS-EXAMENS. } \\
\text { Getal der leerlingen, die }\end{array}$} \\
\hline & 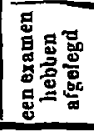 & 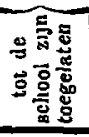 & 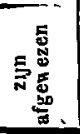 & 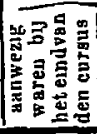 & 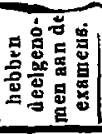 & 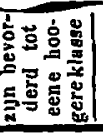 & 突 \\
\hline 's Hertogenboach & 20 & 17 & 3 & 39 & 39 & 20 & 19 \\
\hline Tilburg & 16 & 16 & D & 7 & 7 & 4 & 3 \\
\hline Breda & 10 & 10 & ○ & 21 & 21 & 13 & 8 \\
\hline Helmond & 7 & 7 & $n$ & 43 & 43 & 27 & 16 \\
\hline Arnhem & 26 & 24 & 2 & 58 & 54 & 40 & 14 \\
\hline Nyłmegen & 23 & 20 & 3 & 41 & 32 & 22 & 10 \\
\hline Zutphen & 27 & 27 & v & 46 & 43 & 23 & 20 \\
\hline Zalt-Bommel & 20 & 18 & 2 & 14 & 14 & 7 & 7 \\
\hline 's Gravenhage & 58 & 50 & 8 & 113 & 109 & 89 & 20 \\
\hline Rotterdam & 67 & 57 & 10 & 82 & 82 & 54 & $28{ }^{*}$ \\
\hline Leiden & 33 & 24 & 9 & 76 & 69 & 50 & 19 \\
\hline Dordrecht & 27 & 22 & 5 & 60 & 60 & 45 & 15 \\
\hline Delft & 50 & 48 & 2 & 97 & 77 & 45 & 32 \\
\hline Gouda & 14 & 8 & 6 & 22 & 21 & 12 & 9 \\
\hline Amsterdain & 79 & 73 & 6 & 116 & 116 & 78 & 38 \\
\hline Haarlem & 32 & 29 & 3 & 99 & 97 & 73 & 24 \\
\hline Zaandam & 7 & 7 & $n$ & 38 & 35 & 27 & 8 \\
\hline Alkmaar & 14 & 12 & 2 & 27 & 25 & 20 & 5 \\
\hline Hoorn & 36 & 29 & 7 & - & - & 一 & - \\
\hline Middelburg & 11 & 11 & D & 49 & 48 & 32 & 16 \\
\hline Goes & 12 & 12 & $D$ & 40 & 40 & 30 & 10 \\
\hline Utrecht & 38 & 26 & 12 & 84 & 84 & 47 & 37 \\
\hline Leeuwarden & 22 & 14 & 8 & 50 & 50 & 25 & 25 \\
\hline Harlıngen & 9 & 9 & & 32 & 32 & 22 & 10 \\
\hline Sneek & 20 & 18 & 2 & 64 & 54 & 34 & 20 \\
\hline Zwolle & 23 & 18 & 5 & 59 & 53 & 27 & 26 \\
\hline Deventer & 18 & 18 & y & 42 & 41 & 30 & 11 \\
\hline Kampen & 67 & 53 & 14 & - & - & - & - \\
\hline Enschede & 35 & 35 & D & 36 & 32 & 30 & 2 \\
\hline Groningen & 49 & 43 & 6 & 92 & 81 & 53 & 28 \\
\hline Veendam & 35 & 34 & 1 & 69 & 65 & 46 & 19 \\
\hline Sappemeer & 45 & 42 & 3 & - & - & - & - \\
\hline Warffum & 31 & 31 & v & 一 & - & - & - \\
\hline Assen & 36 & 30 & 6 & - & - & - & - \\
\hline Maastricht & 35 & 26 & 9 & 107 & 55 & 36 & 19 \\
\hline Roermond & 27 & 27 & 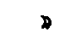 & 76 & 71 & 50 & 21 \\
\hline Venlo & 2 & 2 & 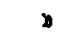 & 27 & 27 & 15 & 12 \\
\hline Totaal & 1081 & 497 & 134 & 1826 & 1677 & 1126 & 551 \\
\hline
\end{tabular}

Fron. 1869. 
Bij dit overricht zij nog het volgende opgemerkt Onder de 1081, die het toelatings-examen aflegd'en, waren er ruim 600 , die zich voor de laagste klabse hadden adngemeld, ruim 400 , die aanstonds tot eene hoogere klasse wenschten tógelaten te worden; eene naauwkeurige opgave is mij hierroor niet mogeluk, daar bij enkele gemeentescholen alle nieuwe leerlıngen eerst voor de laagste klasse wordén geexamineerd en daarna, indıen hunne kemnis meer dan voldoende daarvoor blukt te zijn, ook nog tot het examen voor hoogere klassen worden toegelaten. Ruım 700 zun toegelaten tot de door hen verlangde klasse, ongeveer $200 \mathrm{zijn}$ in eene lagere klasse geplaatst. Het getal van hen, die geheel werden afgewezen, bedroeg 134, dus 12 ten honderd. Deze verhouding 18 niet ougunstig te roemen. Wanneer men echter de onderscheidene scholen met elkander vergelijkt, dan bemerkt men nog al verschll; het zou echter gewaagd zijn daaruit gevolgtrekkingen te maken. Alleen moet niet uit het oog verloren worden, dat het betrekkelijk aanzienlijk getal geëxamineerden te Hoorn, Kampen, Sappemeer, Warffum en Assen daaraan is toe schrijven, dat die scholen toen eerst geopend werden. Het groote getal van 1081 geëxamineerden toont muns inziens, dat de tegenżın tegen de hoogere burgerscholen toch waarlijk niet zoo groot was, als sommigen het wel wilden doen voorkomen!

Nog zij hier opgemerkt, dat bij de Rijksseholen geen elgenlijke toelatings-examens worden gehouden. Volgens het Reglement dier scholen kunnen tot de laagste klasse ook leerlingen zonder examen toegelaten worden. Voor zoo veel mij bekend is geschiedt het evenwel nummer, dat de leerlingen zwarigheid maken om een examen te ondergaan. Wel gebeurt het somtijds, dat de ouders toch voor hunne zoons, die bij het onderzoek te licht beronden zijn, de toelating vorderen; dit was dit jaar, voor zooveel mij bericht is, het geval met 4 leerlingen te Leeuwarden, 3 te Zwolle, 3 te Sappemeer en 1 te Assen.

In de eerste kolom voor de overgangs-examens is het getal verneeld van heu, die bjj het ende van den cursus 1867168 aanwezig waren, wel te verstaan in die klassen, van welke men nog tot eene hoogere kon overgaan. Bij het begin van dien cursus waren er aan de 32 toen bestaande scholen 2064 leerlingen; trekt dan daarvan af het getal der leerlhngen der $5^{\text {de }}$ klasse van de volledige inrichtingen, van de $4^{\text {de }}$ klasse der scholen van vierjarigen cursus en van de $3^{\text {de }}$ klasse der scholen van driejarrgen cursus, te zamen 109, dan blujven er over 1955; van dezen waren er, bij het ende vau den cursus nog 1826 over, zoodat in den loop van dat jaar 
129 leêrlingen de scholēn verlaten hadden. Van deze 1826 hebbeñ 1677 aan de overgangs-examens deelgenomen; de overige 149 niet, hetzij omidat $z i j$ niet voornemens waren na de vacantie terug te komen, hetzij omdat zij voorä wel konden nagaan, dat het examen geen gunstigen uitblag voor hen zou opleveren. Van dieze 1677 zijn 1126 tot eene hoogere klasse bevorterd en 551 afgewezen. Deze verhouding is niet gunstig; mijns inziens moet in 't vervolg het streven zijn om zoo min mogelijk leerlingen eene klasse to laten verdubbelen, en moet dit cijfer althans minder bedragen dan ëen derde gedeelte, zooals in 1868 het geval was. Uit de cijfers in de tabel blijkt, dat ook in idit opzicht bij de onderscheidene scholen nog al verschil bestond; men verlieze evenwel net uit het oog, dat hièr ook bijzondere omstandigheden, vooral de korte tijd, 'sedert de opeuing der scholen verstreken, van grooten invloed kunnen geweest zijn.

Voor de eindexamens, die in 1868 in zeven provincıën zijh gehouden, namelyk in Gelderland, Zurdholland (tevens voor Zeeland), Noordholland, Utrecht, Friesland (tevens voor Groningen), Overijssel en Limburg, hebben zich in 't geheel 80 jongelieden aangemield, van welke 67 ziju toegelaten en 13 afgewezen. Deze uitklag mag zéker gunstig heeten; niet minder gunstig is het te noemén, dät van de 94 leerlıngen, die zich in den cursus $1867 / 68$ in de $5^{\text {de }}$ klasse der verschillende scholen bevonden, 76 aan het eindexamen hebben deelgenomen, terwijl er onder de overigen nog enkelen waren, die reeds kort te voren het examen A voor Indisch ambtenadr ten overstaan van de daarvoor door den Minister van Kolouien benoemde Commissie hadden afgelegd.

De volgende tabel geeft een overzicht van den uitslag der eindexamens, zoowel vau die in 1868, als van de in de beide voorgtande jaren gehoudene, met aanwijzing van de scholen, van welke de kandidaten afkomstig waren. 


\begin{tabular}{|c|c|c|c|c|c|c|c|c|c|c|c|c|}
\hline \multirow[b]{3}{*}{ SCHOLEN } & \multicolumn{6}{|c|}{ GETAL DER KANDIDATEN, } & \multicolumn{4}{|c|}{ IJ HET EINDEXAMEN } & CEN IN & \\
\hline & \multicolumn{3}{|c|}{1866} & \multicolumn{3}{|c|}{1868} & \multicolumn{3}{|c|}{1868} & \multicolumn{3}{|c|}{ Totan } \\
\hline & 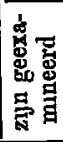 & 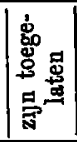 & 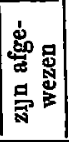 & 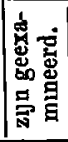 & 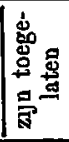 & 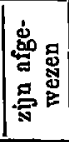 & 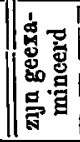 & 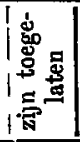 & 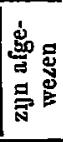 & 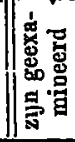 & 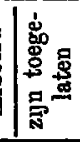 & 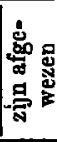 \\
\hline $\begin{array}{l}\text { Hoogere bur- } \\
\text { gerscholen. } \\
\text { Arnhem } \\
\text { Zutphen } \\
\text { 's Gravenhage } \\
\text { Rotterdam } \\
\text { Leiden } \\
\text { Dordrecht } \\
\text { Delft } \\
\text { Amsterdam } \\
\text { Haarlem } \\
\text { Mrddelburg } \\
\text { Utrecht } \\
\text { Sneek } \\
\text { Deventer } \\
\text { Enschede } \\
\text { Groningen } \\
\text { Masstricht } \\
\text { Roermond }\end{array}$ & 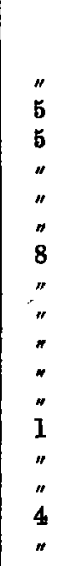 & 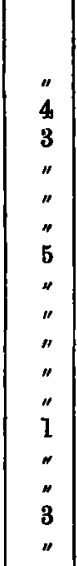 &  & $\begin{array}{l}11 \\
4 \\
6 \\
4 \\
1 \\
1 \\
7 \\
3 \\
9 \\
2 \\
5 \\
3 \\
4 \\
1 \\
5 \\
5 \\
4\end{array}$ & $\begin{array}{l}" 1 \\
\mathbf{3} \\
\mathbf{5} \\
\mathbf{3} \\
1 " \\
1 \\
\mathbf{4} \\
3 \\
7 \\
\mathbf{2} \\
\mathbf{3} \\
1 \\
\mathbf{3} \\
1 \\
4 \\
1 \\
\mathbf{3}\end{array}$ & $\begin{array}{l}" \prime \\
1 \\
1 \\
1 \\
" \prime \\
3 \\
3 \\
2 \\
z \\
2 \\
2 \\
1 \\
" 1 \\
1 \\
4 \\
1\end{array}$ & $\begin{array}{l}2 \\
3 \\
7 \\
5 \\
3 \\
3 \\
8 \\
4 \\
9 \\
1 \\
6 \\
4 \\
6 \\
2 \\
4 \\
6 \\
3\end{array}$ & $\begin{array}{l}2 \\
2 \\
3 \\
5 \\
3 \\
2 \\
7 \\
3 \\
9 \\
1 \\
5 \\
3 \\
6 \\
2 \\
4 \\
5 \\
3\end{array}$ & $\begin{array}{l}3 \\
1 \\
4 \\
" \prime \\
1 \\
1 \\
1 \\
1 \\
\prime \prime \\
1 \\
1 \\
\text { " } \\
\text { " } \\
1 \\
1\end{array}$ & $\begin{array}{r}2 \\
12 \\
18 \\
9 \\
3 \\
4 \\
23 \\
7 \\
18 \\
3 \\
11 \\
7 \\
11 \\
3 \\
9 \\
15 \\
7\end{array}$ & $\begin{array}{r}2 \\
9 \\
11 \\
8 \\
3 \\
3 \\
16 \\
6 \\
16 \\
3 \\
8 \\
4 \\
10 \\
3 \\
8 \\
9 \\
6\end{array}$ & $\begin{array}{l}4 \\
3 \\
7 \\
1 \\
1 \\
1 \\
7 \\
1 \\
2 \\
4 \\
3 \\
3 \\
1 \\
\prime \prime \\
1 \\
6 \\
1\end{array}$ \\
\hline $\begin{array}{c}\text { Totaal } \\
\text { Techn. school } \\
\text { te Utrecht, } \\
\text { voorbereidende } \\
\text { carsus der Po- } \\
\text { lytechn.school, } \\
\text { bjyzondere in- } \\
\text { stellingen en } \\
\text { priv. onderw. }\end{array}$ & 23 & 16 & 7 & 63 & 44 & 19 & 76 & 65 & 11 & 162 & 125 & 37 \\
\hline Alg. totaal. | & 38 & 26 & 12 & 73 & 48 & 25 & 80 & 67 & 13 & $\|_{191}$ & 141 & 50 \\
\hline
\end{tabular}

Hierbij valt niets anders op te merken, dan dat de voor Sneek in 1868 als afgewezen opgegeven kandidaat zich nog voor het einde van het mondeling examen uit eigen beweging heeft teruggetrokken; ik meende hem evenwel hier onder de afgewezenen te moeten tellen.

\section{§6. De kosten.}

In de paragraaf, waarin over het onderwijzend personeel is gesproken, komt eene uitvoerige opgave voor van de jaarwedden der leeraren, zoowel aan de Rijksscholen als aan de gemeentelyke inriçhtingen De overige kosten dier scholen zijn niet gemakkelijk optegeven, daar mij de gegevens daartoe grootendeels ontbreken. Vit 
een overzicht, ann het slot van dit opstel mede te deelen, zal blijken, hoeveel in 't geheel door het Rijk en de gemeenten in 1866, het laatste jaar waarover tot dusverre door de Regeering opgaven gedaun zijn, aan het middelbaar onderwijs is besteed, en wat aan schoolgelden is opgebracht. Bovendien waren de uitgaven in dat jaar voor de meeste hoogere burgerscholen nog niet tot een normalen toestand gekomen, daar er hetzij voor de gebouwen, hetzij voor hulpmiddelen nog vele buitengewone te doen waren.

De kosten der Rijksscholen hebben in de Staten-Generaal tot langdurige beraadslagingen en vele annmerkingen aanleiding gegeven, zooals boveu reeds is vermeld. Het komt mij geheel overtollig voor andermaal daarop terug te komen. Alleen laat ik hier eene opgave volgen van hetgeen volgens den Minıster jaarluks voor die scholen zal worden vereischt, wanneer zij zich alle in een normalen toestand zullen bevinden.

De jaarwedden van het onderwijzend personeel bedroegen bij het einde van 1868 rulm $f 270000$; daarbij komen nog die van het dienstdoende personeel (concierge's, amanuenses en dergelijke), alsmede die van het personeel der nog te openen school te Heerenveen. Het geheele bedrag der jaarwedden kan dus gesteld worden op ongeveer $f 300000$ Voor eventueel te verleenen jaarwedden, wanneer splitsing van klassen vermeerdering van leeraren noodig mocht maken, wordt eene som van ongeveer $f 17000$ beschikbaar gehouden. Voor het onderhoud der gebouwen wordt voor iedere school gemiddeld $f 1000$ 's jaarlijks noodig geacht; voor hulpmiddelen voor het onderwijs, vuur en licht, kosten van het schoonhouden der localen en dergelijke uitgaven rekent men voor iedere school van vufjarigen cursus gemiddeld $f 3500$, voor eene van driejarıgen cursus $f 2500$ 's jaars noodig te hebben. De kosten van het materieel zullen dus $f \mathbf{6 3 0 0 0}$ 's jaars vorderen De totale uitgaven worden derhalve, zoo er geen buitengewone te doen zijn, op $f 380000$ 's jaars gesteld. Op de Staatsbegrooting voor 1869 staat eene som van $f 490000$ uitgetrokken; die hoogere som is veroorzaakt door de kosten van de gebouwen voor de Ryksscholen te Groningen en te Heerenveen.

Ik heb in het vorig opstel het bedrag van het schoolgeld voor sedere school vermeld. Daar er nog eenige nieuwe bijgekomen zijn, laat ik hier eene volledige opgave volgen, zoowel voor het volledig onderwijs als voor het bijwonen van enkele lessen.

Folledrg onderwijs. $f 20$ tot $f 50$, naar gelang van de klassen, wordt betaald te Veendam;

$f 22$, te Venlo; 
$f 30$, te 's Hertogenbosch, Tilburg, Helmond, Zult-Bommel, Gouda, Alkmaar, Kampen, Sappemeer, Warffum, Assen, Maastricht en Roermond;

$f 30$ tot $f 50$, naar gelang van de klassen, te Sneek;

$f 40$, te Mrddelburg en Harlingen;

$f 40$ tot $f 50$, naar gelang van de klassen, te Hoorn en te Goes;

$f 50$, to Breda, Leeuwarden, Zwolle en Groningen;

$f 50$ tot $f 60$, naar gelang van de klassen, te Deventer;

$f 54$ tot $f 72$, naar gelang van de klassen, te Dordrecht,

$f 60$, te Arnhem, Nijmegen, Zutphen, 's Gravenhage, Rotterdam,

Lerden, Haarlem, Zaandam en Utrecht;

$f 70$, te Delft en Enschede;

$f 90$, te Amsterdam.

Enkele lessen. $f 2$ 's jaars per lesuur 's weeks, te Harlungen;

$f 3$ per lesuur 's weeks, te Breda;

$f 3$ tot $f 12$ per vak, te Sneek en Deventer;

$f 5$ per uur 's weeks, te Nijmegen;

$f 5$ tot $f 10$ per vak, te Maastricht en Roermond;

$f 5$ tot $f 12$ per vak, te Goes;

$f 5$ tot $f 20$ per vak, te Enschede;

$f 6$ en hooger per vak, te Arnhem;

$f 7$ tot $f 14$ per vak, te 's Hertogenbosch, Tilburg, Helmond, Zalt-Bommel, Gouda, Alkmaar, Middelburg, Sappemeer, Warffum en Assen;

$f 7.50$ tot $f 15$ per vak, te Leeuwarden, Zwolle en Groningen;

$f 10$ per vak, te Kampen;

$f 10$ tot $f 15$ per vak, te Dordrecht;

$f 10$ tot $f 20$ per vak, te Zutphen en Utrecht,

$f 10$ tot $f 25$ per vak, te Leiden, Amsterdam en Haarlem;

$f 10$ tot $f 30$ per vak, te Delft;

$f 10$ tot $f 40$, te Hoorn;

$f 20$ per rak, te Zaandam.

Dat de schoolgelden over het algemeen laag gesteld zijn, kan door niemand ontkend worden. Men moet evenwel daarbij niet uit het oog verhezen, dat bij de Wet zelve het schoolgeld voor de Rijksscholen op een maximum van $f 60$ is gesteld. Het lag dus op den weg der gemeentebesturen in dit opzicht niet belangrijk hooger te gaan. Waar men het deed, zoo als te Amsterdam, waar het aanvankelijk $f 180$ bedroeg, ondervond men daarvan de gevolgen in het klein getal der leerlingen. Toen men daar het schoolgeld in 1867 tot $f 90$ verminderde, klom het getal leerlingen vrij aanzienlijk, 
en het lijdt bij mij geen twuffel, of het betrekkeluk gering getal leerlingen in de hoofdstad is nog grootendeels toe te schrijven aan het schoolgeld van $f$ 90, dat, zooals ook de Minister in de Tweede Kamer te kennen gaf, voor velen nog te hoog 18.

Eene naauwkeurige statistiek van de opbrengst der schoolgelden kan ik niet geven, eerst over eenige maanden zou die voor het jaar 1868 kunneu gegeven worden. Volgens eene zeer matige berekening, gegrond op het in December 1868 aanwezige getal leerlingen en het hedrag $\operatorname{ran}$ het door iederen leerling te betalen schoolgeld, mag de geheele opbrengst voor het schooljuar $1868 / 69$ op ongeveer $f 120000$ gesteld worden. Deze som is slechts een betrekkeljk gerıng gedeelte van de kosten der 37 bestaande hoogere burgerscholen, die $\mathrm{kk}$ in normalen toestand op ongeveer $f 750000$ schat. Enkele leden der Staten-Generaal hebben in het groote verschil aanleidng gevonden om met kracht tegen die lage schoolgelden op te komen en het beginsel op den voorgrond te stellen, "dat men er naar moet streven, dat de kosten geheel door het ,schoolgeld gedekt worden." Deze leer, die echter net nieuw is, werd zoowel in de Eerste als in de Tweede Kamer verkondigd; dat zij onhoudbaar is, laat zich met een paar cijfers gemakkelijk aantoonen.

Stellen wij in ronde cyfers, dat er 3000 leerlıngen ziju, die $f 120000$ aan schoolgeld, dus elk gemiddeld $f 40$, betalen, doch dat de kosten $f 750000$ bedragen. Om die alle te dekken zou redẹr leerling $f 250$ moeten betalen; maar gesteld eens, dat men zich vooreerst tot streven zou willen bepaleu en zich dus te vreden stellen, indien de helft slechts der kosten werd vergoed, dan zou toch nog het schoolgeld van $f 40$ tot $f 125$ moeten klimmen. Hoevęel zouden er van die 3000 leerlingen in dat geval nog overblijveṇ? Men zal mị nıet van overdrijving beschuldigen, indien lk aannepm, dat het getal aanstonds met 1000 zou verminderen, maar die vermindering maakt weder op nieuw verhooging van het schoolgeld noodig, want om het beginsel in stand te houden moeten nu die 2000 overbljivende leerlingen dezelfde som van $f 375000$ opbrengen, dus elk curca $f 190$ betalen. Die verhooging zal echter weer tot een nieuwe verminderıng van leerlingen leiden; en het laat zich duidelijk inzien dat men, op die wujze voortgaande, tot het besluit moet komen, dat het onmogelijk is aan dezen eisch te voldoen. Wanneer men den toestand in andere landen, zooals de Duitsche Staten en Belgje, nagaat, dan vindt men, dat het er zeer ver van verwijderd is, dat de kosten van het muddelbaar on- 
derwiss door de opbrengst der schoolgelden kunnen bestreden worden, en dat men ook daar heeft ingezien, dat een laag schoolgeld voor die inrichtingen eene eerste behoefte, ja eene levenskwestie is. Als men het schoolgeld bij de Duitsche Reaalscholen, bij de Belgische Athénées en Ecoles moyennes vergelijkt bij hetgeen aan onze hoogere burgerscholen wordt betaald, dan zal men zien, dat het bij ons in den regel nog vrij wat hooger gesteld is.

Eindelijk moet ook niet uit het oog worden verloren, dat, zoo als in de Tweede Kamer zeer terecht door den heer Dam werd opgemerkt, het schoolgeld nuet het eenige is, wat de ouders te betalen hebben, maar dat ook de boeken, teeken- en schrijfbehoeften ten hunnen laste komen, die voor deze scholen zeer aanzienlijk zijn, ja voor sommige klassen bijna even veel als het schoolgeld zelf bedragen.

\section{De middelbare school ooor meisjes le Haarlem.}

Behalve de in mijn vorig opstel vermelde middelbare school voor meisjes te Haarlem is er un 1868 geen nieuwe opgencht. Die inrichtıng verkeert un guustıgen toestand. Het getal der lecrlıngen, dat in 186734 bedroeg, is thans geklommen tot 53 , die als volgt over de 4 luagste klassen verdeeld zijn, de hoogste of $5^{e}$ klasse heeft nog geen leerlingen.

\begin{tabular}{|c|c|c|c|c|c|c|c|c|}
\hline \multirow{2}{*}{ KLASSEN } & \multicolumn{7}{|c|}{ GETAL DER LEERJINGEN } & \multirow{2}{*}{ Totaal } \\
\hline & $\begin{array}{l}\text { beneden } \\
12 \text { jaren }\end{array}$ & $\begin{array}{l}12-13 \\
\text { jaren }\end{array}$ & $\begin{array}{l}\text { lo-1t } \\
\text { jaren }\end{array}$ & $\begin{array}{l}14-15 \\
\text { juren }\end{array}$ & $\begin{array}{c}15-16 \\
\text { juren }\end{array}$ & $\begin{array}{l}16-17 \\
\text { laren }\end{array}$ & $\begin{array}{l}17-18 \\
\text { jaren }\end{array}$ & \\
\hline $\begin{array}{l}\text { le klasse. } \\
2 e \text { klasse. } \\
\text { 3e klasse. } \\
\text { 4e klasse. }\end{array}$ & $\begin{array}{l}7 \\
D \\
0 \\
0\end{array}$ & $\begin{array}{l}7 \\
3 \\
1 \\
1\end{array}$ & $\begin{array}{l}6 \\
7 \\
2 \\
0\end{array}$ & $\begin{array}{l}3 \\
3 \\
1 \\
2\end{array}$ & $\begin{array}{l}n \\
3 \\
1 \\
n\end{array}$ & $\begin{array}{l}n \\
2 \\
2 \\
1\end{array}$ & $\begin{array}{l}\text { y } \\
\text { " } \\
\text { n } \\
3\end{array}$ & $\begin{array}{r}23 \\
16 \\
7 \\
7\end{array}$ \\
\hline Totaal & 7 & 12 & 15 & 9 & 4 & 3 & 3 & 53 \\
\hline
\end{tabular}

In de regeling van het ondelwijs is geen veranderıng gekomen, behalve de urtbıerdıng, welke het in 1868 door opening der $4^{e}$ klasse onderging.

Het onderwijzend personeel bestaat uit eene directrice met eene jaarwedde van $f 1600$ en vrije woning, drie onderwijzeressen met jaarwedden van $f 800$ en vijf leeraren. Van de vier dames hebben drie eene acte als hoofdonderwijzeres en twee eene acte voor middelbaar onderwijs in levende talew. Van de leeraren is een kandidaat in de wis- cn natuurkunde, belast met het ouderwijs 
in w18-, natuur- en schelkunde; deze is uitsluttend aan de me1sjesschool verbonden op eene jaarwedde $\operatorname{van} f 1600$; het onderwijg in natuurlijke historie, in boekhouden, in teekenen en in gymnastiek is opgedragen aan de vier leeraren, die dit onderwijs geven aan de hoogere burgerschool; het gezamenlijk bed rag der jaarwedden is thans $f 6800$, wanneer men rekent, dat de helft der jaarwedde van den leeraar in nat. hrstorie voor rekenung der meisjesschool komt. Voor schoolgeld wordt $f 50$ 's jaars betaald.

Een herhaald bezoek van deze school heeft bij mij een gunstigen undruk nagelaten, vooral sedert op eene meer definitieve wijze voor de behoefte uan onderwijzend personeel $1 \mathrm{~s}$ gezorgd. Ik hoop zeer, dat het roorbeeld van Haurlem elders navolging moge vinden.

BURGERSCHOLEN.

Het getal der burgerscholen heeft in 1868 geen groote vermeerdering ondergaan. De burgerdag- en avondscholen zijn van drie tot vijf toegenomen, daar er, behalve de reeds in 1867 bestaande te 's Gravenhage, Utrecht en Groningen, nog twee in werkıng zijn gekomen, namelijk te Amsterdam en te Leeuwarden.

Burgeravondscholen, krachtens art. 14 der Wet opgericht, waren er in 1867 dertien, namelık te Breda, Arnhem, Nijmegen, Zutphen, Dordrecht, Delft, Gouda, Haarlem, Zaandam, Middelburg, Harlıngen, Deventer en Maastricht. In 1868 zijn daar nog brjgekomen die te $\mathrm{Z}$ wolle en te Kampen. Bovendien is aan de regelingsplannen te Rotterdam gedeeltelyk uitvoering gegeven. Eene burgerdagschool is er nog niet in werking gekomen, maar de door de gemeente gesubsidieerde Akademie van Beeldende Kunsten en Technische Wetenschappen heeft eene reorganisatie ondergaan, waardoor aan het onderwijs eene uitbreiding is gegeven, welke die inrichting op ruime schaal doet beantwoorden aan de elschen, door de Wet voor eene burgeravondschool gesteld.

Aangaande de vroeger bestaande inrichtingen is niets meer mede te deelen, dan in mijn vorig opstel daarover is gezegd. Te Groningen wordt de burgerdag- en avondschool door dezelfde leerlingen bezocht; deze twee zijn onafscheidelijk met elkander verbonden. op de tabellen heb ik die te zamen als burgerdagschool vermeld. Daarentegen beb ik de „burgeravond school voor voortgezet onderwijs," die bestemd is om in datgene te voorzien, wat de wetgever met de burgeravondschool beoogde, daarop als burgeravondschool ver- 
meld. Men schijut echter daar in te zien, dat de burgerdagschool weinig wordt bezocht door die leerlingen, waarvoor de wetgever haar bestemde, en dat dientengevolge ook de burgeravondschool voor voortgezet onderwijs, tot welke alleen leerlingen worden toegelaten, die den cursus der dagschool hebben ten eingde gebracht, evenmin in de behoefte voorziet Het gemeentebestuur heeft daarom het voornemen opgevat nog eene tweede burgeravondschool in 't leven te roepen, meer bestemd voor leerlingen uit den ambachtsstand, die over dag zich reeds met de urtoefening van eenig ambacht bezig houden. Die nieuwe inrichting was evenwel bij het einde van 1868 nog niet in werking getreden.

Te 's Gravenhage telt de burgeravondschool nog geen leerlingen en bestaat dus eigenlijk niet $\mathrm{De}$ teeken-alsademie aldaar voorziet nog niet in de behoefte aan dit onderwjs, daar zj zich uitsluitend tot hand- en rechtlijnig teekenen en boetseeren bepaalt; zij staat nog in geen verband met de burgerdagschool en is daarom in deze statistiek evenmin vermeld als de in vele andere gemeenten krachtens het Kon. besluit van 13 April 1817 opgerichte teekenscholen.

Voor de regeling van de overige reeds un 1867 bestaande scholen meen ik naar het vroeger gegeven overzicht te mogen verwijzen, ep bepaal mij thans tot de in 1868 voor het eerst geopende.

De burgerdag- en avondschool te Amsterdam is in September 1868 geopend. Volgens het reglement zal de dagsehool van een tweejarigen cursus zijn; eveneens de avondschool; men is evenwel voornemens de gelegenheid te openen om het onderwijs in enkele vakken, bepaald in teekenen, ook toegankeljkk te stellen voor hen, die den tweejarigen cursus reeds hebhen doorloopen. Dezen winter is echter nog slechts ééne klasse der burgerdagschool en ééne der avondschool geopend.

Te Leeuwarden zullen zoowel de burgerdagschool als de burgeravondschool van een tweejarigen cursus zijn; aan beide is echter voor dit schooljaar nog slechts ééne klasse aanwezıg. De avondschool verkeert bovendien, daar de daarvoor bestemde localen nog niet gereed zijn, in een overgangstqestand, die niet gunstig werkt. Het zou dus onbillijk zijn daarover thans reeds een bepaald oordeel te vellen.

Aangaande de burgeravondscholen te $Z_{\text {wolle }}$ en te Kampen is nog weinig mede te deelen; besde tellen wog slechts eene enkele klasse $\mathrm{Te} \mathbf{Z}$ wolle is tevens eene druk bezochte teekensohool, die, hoewel niet onder het bestuur van den directeur der burgeravond- 
achool, nogtans met die inrichting in zeker verband stąt; ik heb daarom gemeend die ook hrer te moeten vermelden.

De Akademie van Beeldende Kunsteu en Technische Wetensehappen te Rotterdam bestaiat uit drie afdeelingen. De afdeeling $A$ is bestemd noor opleiding in de beeldende kunsten; daar wordt onderwijs gegeven in handteekenen, boetseeren en ornament, geschiedenis der heeldende kunsten en der bouwkunde. Aan de afdeeling $B$, bestemd yoor technische wetenschappen voor den bouwkundige en den bandWerksman, wordt onderwijs gegeven in wis-, natuur-, schei- en werktuigkunde, en in hand- en rechtlijnig teekenen in zijn geheelen omvang. Ferscheidene leerlingen wonen zooveel mogelijk het onderwijs aan deze helde afdeelingen by. De derde afdeeling $\mathrm{C}$ js bestemd voor yoorbereldend onderwijs in lezen, schrijven en rekenen. De afdeelịgen $\mathrm{A}$ en $\mathrm{B}$ tellen ieder zes klassen, de afdeeling $\mathrm{C}$ drie.

Ik heb in de volgende tabellen, die op de burgerscholen betrekkng hebben, de burgerdagscholen van de burgeravondscholen geschelden ook dap wanneer zij in dezelfde gemeente aanwezig zijn; dit kwam mij voor in overeenstemming te zijn met den aard der scholen en het soort der leerlingen De eerstrolgende tabel heeft betrekkıng op het getal en den leeftijd der leerlingen. Het teeken (") duidt ąan, dat de klasse nog geen leerlingen telt, een streepje, dat zij volgens de organisatie niet zal bestaan. 

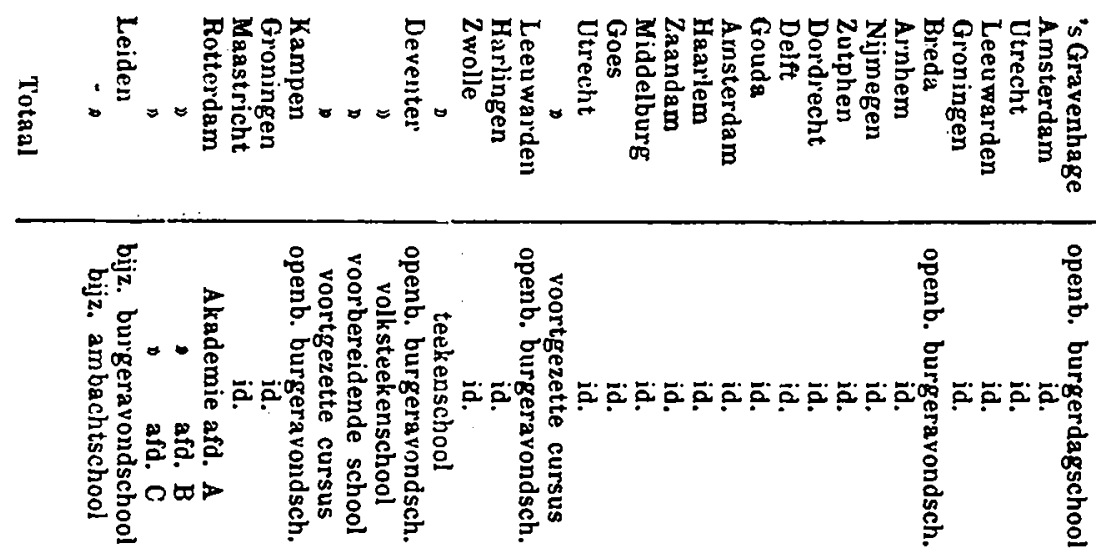

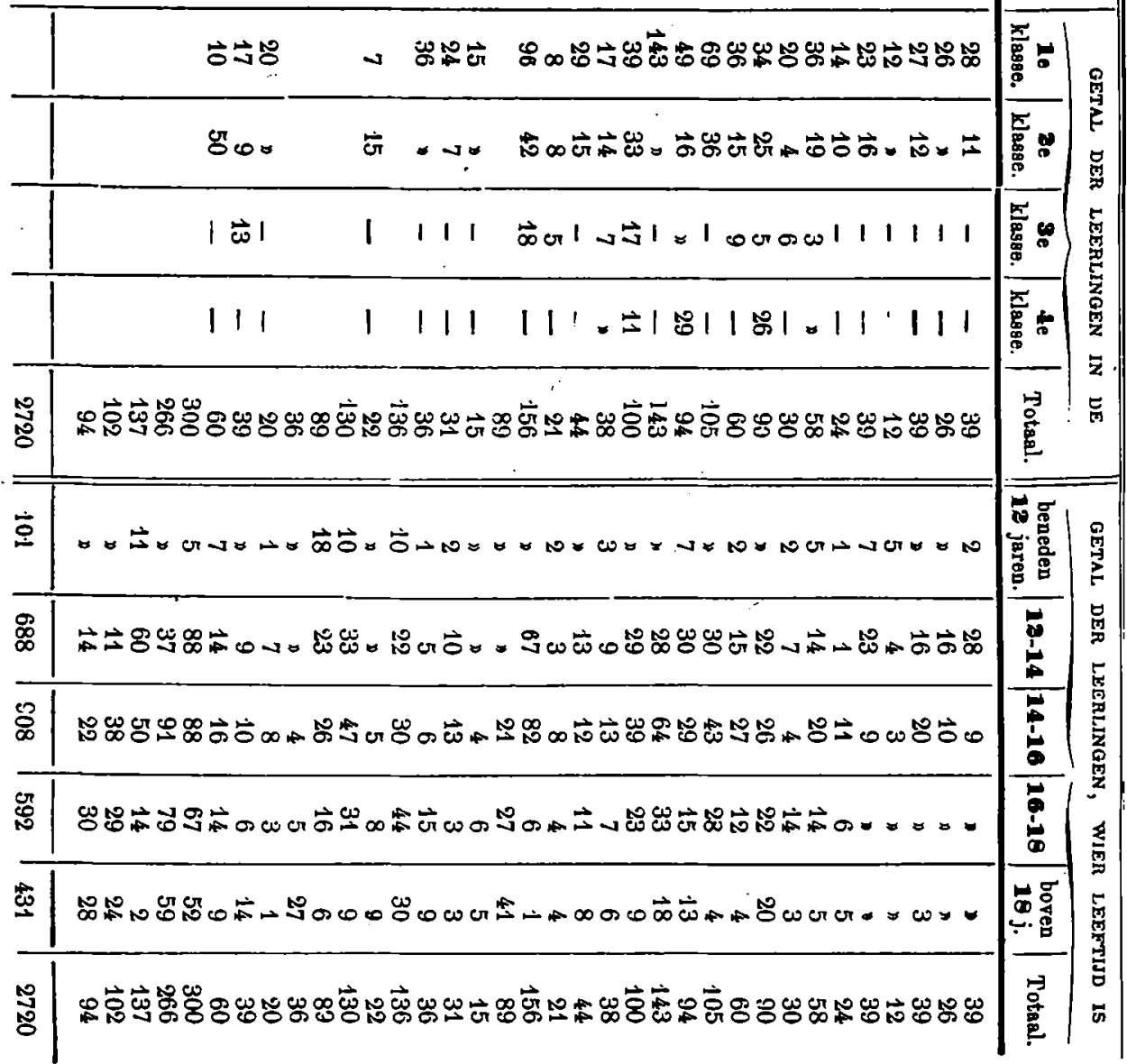


Voor sommige scholen ontbreekt eene opgave van het getal der leerlingen voor elke klasse afzonderlijk. Dit is alleen daaraan toe te sohrijven, dat de leerlingen niet zoo bepaald in klassen verdeeld zijn of ook wel het onderwijs in verschillende klassen bijwonen. Daarom konden ook van de vier eerste kolommen met cijfers geen totalen opgegeven worden.

Het geheele getal der leerlingen bedroeg 2720 , van welke 155 gebruik maakten van de vijf burgerdagscholen, 1666 van de twintig openbare burgeravondscholen en daarmede verbonden inrichtingen, en 899 van de beide bijzondere instellingen te Rotterdam en te Leiden. In December 1867 maakten slechts 1569 leerlingen van dit onderwijs gebruik; de vermeerdering is echter grootendeels toe te schrijven aan de thans voor het eerst opgenomen scholen te Amsterdam, Leeuwarden, Zwolle, Kampen en Rotterdam, die te zamen 1091 leerlingen tellen. Voor de vroeger bestaande bedraagt dus de vermeerdering slechts 60 . Het getal der leerlngen groeide aan te Utrecht, A rnhem, Nijmegen, Delft en Gouda; het onderging eenige vermindering te Groningen, Zatphen, Haarlem, Middelburg en Maastricht, aan de overige scholen bleef het nagenoeg onveranderd.

Even als het vorige jaar ben ik thans weder in staat eene vrij volledige opgave te doen van het ambacht, het beroep of de betrekking, waarin de leerlingen dezer scholen werkzaam zijn, of, indien zij nog geen keuze hebben gedaan of over dag de school bezoeken, van het beroep der ouders. Tk heb eenvoudigheidshalve weder dezelfde hoofdafdeelingen als het vorige jaar aangenomen; behalve dat voor hen, die tot bouwkundigen bestemd zijn, eene afzonderlijke kolom is geopend.

Uit deze opgaven (zie bl. 454) blijkt. dat van de 155 leerlingen der burgerdagscholen slechts 48 , dat is minder dan een derde gedeelte, tot den ambachtsstand behooren, terwijl nagenoeg evenveel, namelijk 45, zoons zijn van ambtenaren, onderwijzers, militairen en dus naar alle waarschijnlijkheid niet voor een ambacht bestemd. Hetzelfde kan men zeggen van de 35 zoons van winkeliers en kooplieden; onder de 10 zoons van kunstenaars en bouwkundigen en de 17 zoons van weduwen enz. kunnen er zijn, voor wie de wetgever inderdaad deze scholen bestemde. De uitromst is dus nog niet 

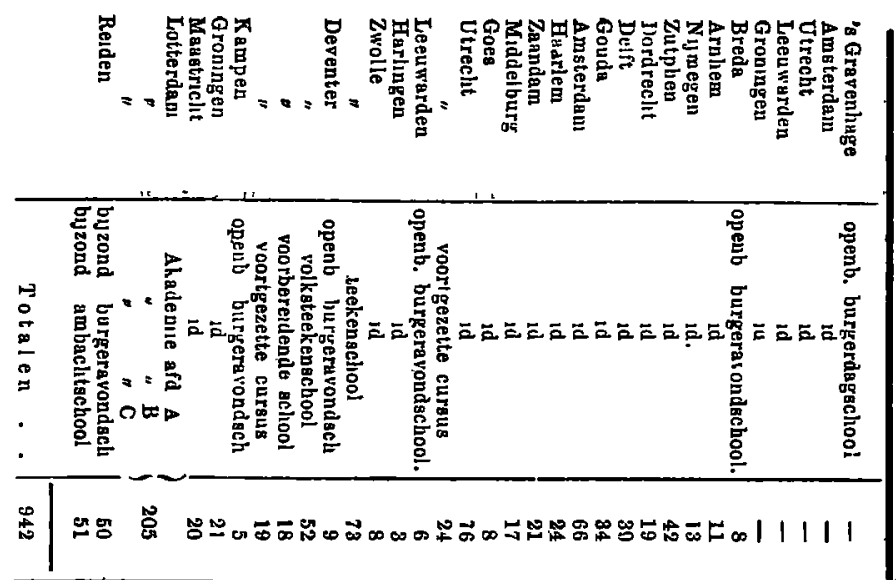

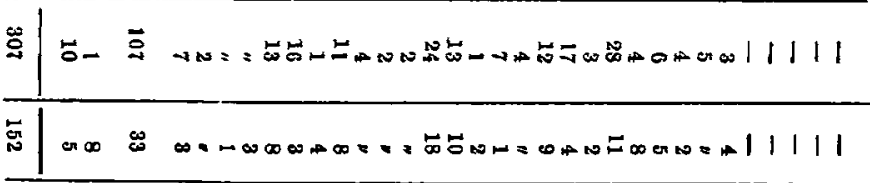

总 On L

D

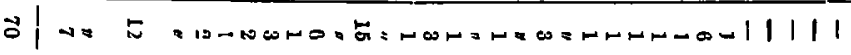



步

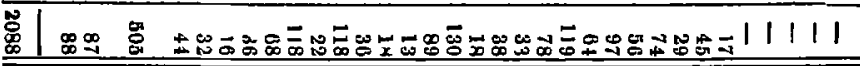


wagen makers

Smeden, gewtermakers, nstrumentmak , kopersiagers

Steenhouwers,

metselaars,

loodgreters

Beeldhouwers,

etukadoors,

goudsmeden,

graveurs en

lithografen

Schtlders en glazenmakers, verJakkers

Bouwkundigen

Ambacliten onder

de voorgande niet rerbeld

K weekl elıngen,

onderwizzers,

kantoorbedienden

klerken.

Totaal,

Ambachtsheden

Winkelıers en

kooplieden

Kunstenaars,

bouwkundigen

$\Delta$ mbtens en, onderwyjzers en militairen.

Zonder beroep, moeder weduwe of niet opgegeven

Totaar. 
gunstiger dan het vorıge jaar. Ool het getal leerlingen is nog gering, vooral wauneer men in anumerking neemt, dat de vijf burgerdagscholen zijn gevestigd in vijf van de aanzienlijkste gemeenten van het Rijk. De burgerdagschool te 's Gravenhage schijnt vooral in dit opzicht nog wernig aan de bedoeling van den wetgever te beantwoorden; evenzoo die te Leeuwarden, maar het uiterst gerıng getal leerlıngen maakt het moeilijk hier een bepaald oordeel uit te spreken.

Met de burgeravondscholen en de berde inrichtingen te Rotterdam én te Leiden is het daarentegen beter gesteld Van de 2565 leerlingen, die aldaar onderwijs ontrangen, zijn er 1960, die reeds een ambacht uitoefenen of leeren, en 128, dat is slechts 5 ten houderd, die als onderwljzers, kweekelingen of klerken op een kantoor werkzaam zijn. De 477 overigen oefenen nog geen beroep uit; dezen zijn in den regel beneden 14 jaren. Tot mijn leedwezen kan ik van de maatschappelıjke betrekking hunuer ouders geen volledig overzicht geven, daar mij die voor de 198 leerlingen der Akademie van Beeldende Kunsten te Rotterdam niet is opgegeren. Van de 279 overıgen zjjn 118 zoons van ambachtslieden, 55 van winkeliers of kooplieden, 23 van bouwkundigen of kunstenaars, 37 van ambtenaren, onderwijzers of militarren, terwijl van 46 de ouders geen beroep uitoefeuen of overleden zyn.

Ik mag hier niet onvermeld laten, dat de burgeravondscholen nog met veel moelijkheden te worstelen hebben, die in vele opzichten een hinderpaal zijn voor de vorderingen der leerlingen. In de eerste plaats toch wordt in de meeste gemeenten nog zeer weinig medewerking ondervonden van die ambachtsbazen, die zelven in hunne jeugd mets geleerd hebben dan een wernig teekenen en het dus volkomen overtollig vinden, dat hunne ambachtslieden door beter onderwijs meer kennıs en ontwkkelıng opdoen, dan zij zelven bezitten; niet weinigen doen meer hun best om hen vah de burgeravondschool af te houden dan hen er toe aan te moedigen. Het durdelykst blyjkt dat, wanneer in het laatst van Februarij en vooral in Maart de dagen beginnen te lengen en de jongens dus wat langer aan het werk kunuen gehouden worden; de meesten kunnen dan geen verlof bekomen om het wat vroeger te verlaten ten einde de school te bezoeken. Om hiern te gemoet te komen, heeft men wel in eenige gemeenten met 1 Maart een beperkten cursus ingevoerd, volgens welken het onderwijs een uur later aanvangt; madr zelfs in weerwil daarvan wordt het schoolbezoek tegen het voorjaar byjua overal ongeregeld, en blijven niet weinig lecrlıngen voor goed 
weg. Komen zij dan den volgenden cursus terug, dan is bijna alles weêr vergeten en moeten zij weder van voren af aan beginnen. Bij enkele scholen heeft men een zomercursus ingevoerd, ten einde althans aan die leerlingen, die het begeeren, de gelegenheid te geven om het geleerde te onderhouden.

Nog een bezwarr is gelegen in de opvatting van vele leerlingen, dat voor de uitoefening van hun ambasht het teekenen hun wel nuttig is, maar niet de kennis van wiskunde en van natuur- en werktuigkunde; konden zij alleen de teekenlessen bijwonen, zij zouden wel komen, maar zijn zij verplicht ook het andere onderwijs te volgen, dan blijven zij liever weg. Wilde men het bezoeken van dit laatste facultatief stellen, men zou zeker in 't geheel meer leerlingen trekken, maar het getal van hen, de iets van de wisen natururkundige wetenschappen leeren, zou aanzienlijk verminderen. In dit opzicht, even als voor zooveel den invloed der bazen op het schoolbezoek der jongens betreft, moet dus de hoop op de toekomst gevestigd blijven, terwijl het vooral wenschelijk is, dat zij, die in dit opzicht helderder denkbeelden kunnen verspreiden, hunne medewerking niet onthouden.

In de volgende tabel heb ik alles vereenigd, wat op het onderwijzend personeel der burgerscholen en daarmede verbonden inrichtingen betrekking heeft. I $k$ heb daann eenvoudigheidshalve de in zekeren zin bij elkander behoorende scholen vereenigd, daar anders hetzelfde personeel meermalen zou voorkomen; dit is thans slechts het geval met één leeraar, die tevens aan de burgerdag- en avondschool te Amsterdam en aan de hoogere burgerschool en burgeravondschool te Zaandam onderwijs geeft in de gronden der staathuishoudkunde.

Uit de tabel zelve blijkt, dat er 227 leeraren aan deze scholen onderwije geven, waaronder 96 leeraren aan hoogere burgerscholen; onder de 131 overige zijn er verscheiden, die over dag aan eene lagere school werkzaam zijn.

Wat de jaarwedden betreft, zoo heb ik ook hier, evenals boven voor de hoogere burgerscholen, eenvoudigheidshalve eenige hoofdafdeelingen aangenomen, door de grenzen aangewezen. Die $\operatorname{van} 6$ leeraren te Goes, die tevens aan de hoogere burgerschool werkzaam zijn, zijn niet vermeld, daar zij hunne jaarwedden in die dubbele betrekking genieten (zie boven bladz. 359); evenzoo die voor de 5 leeraren te Kampen, waar de splitsing der jaarwedden nog niet had plaats gehad, toen mij de opgaven door den directeur werden toegezonden 


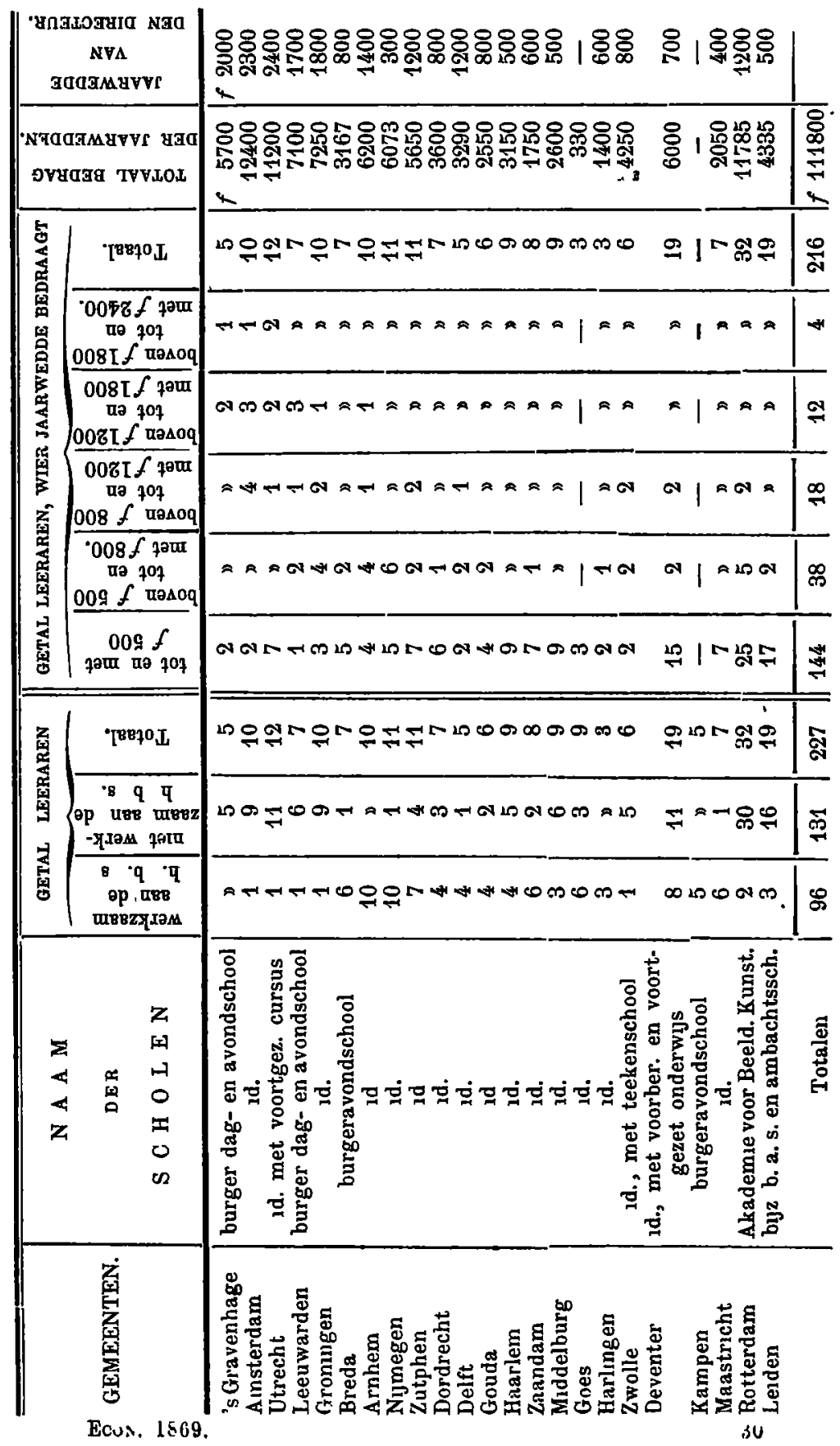


Beschouwt men de vijf burgerdag- en avondscholen afzonderlijk, dan bedragen de jaarwedden der 44 daaraan werkgame leeraren te zamen $f$ 43650, dus gemiddeld elk nagenoeg $f 1000$ De 172 jaarwedden van leeraren aan burgeravondscholen en daarmede verbonden inrichtingen (de bovengemelde 11 te Goes en Kampen niet medegerekend) bedragen $f 68150$, dus gemiddeld nagenoeg $f 400$. Er zijn er onder dezen in 't geheel 129 beneden of van $f 500$ en slechts 43 dearboven. Hierbij is evenwel niet uit het oog te verliezen, dat de meesten dezer leeraren, óf als leeraar aan de hoogere burgerschool, of als onderwijzer aan eene lagere school, bovendien eene jaarwedde genieten.

Wat de jaarwedden der directeuren betreft, moet nog vermeld worden, dat die der burgerdag- en avondscholen te 's Gravenhage en Amsterdam bovendien eene vrije woning hebben. Aangaande de betrekkelijk hooge jaarwedden van sommige directeuren van burgeravondscholen meen $\mathrm{kk}$ te mogen verwijzen naar hetgeen reeds hierv66r in het hoofdstuk over de hoogere burgerscholen daarover is opgemerkt.

Aangaapde de programma's der burgerscholen zal ik thans in geen bijzonderheden treden. In hetgeen ik in mijn vorig opstel dienaangaande opteekende is geen wijziging gekomen van genoeg belang om er hier uitdrukkelijk melding van te maken.

Ook de schoolgelden hebben geen wijziging ondergaan. Volledigheidshalve laat ik echter hier een overzicht daarvan volgen.

\section{Burgerdayscholen}

$f 12$ 's jaars te 's Gravenhage, Amsterdam en Utrecht;

$f 8$ 's jaars, te Leeuwarden en Groningen.

Burgeravondscholen.

$f 8$ 's jaars, te Nijmegen;

$f 6$ 's jaars, te 's Gravenhage, Breda, Arnhem, Zutphen en Zwolle;

$f 5$ 's jars, te Leeuwarden, Groningen, Zaandam en Harlngen;

$f 4$ 's jaars, te Haarlem, Goes en Maastricht;

$f 3$ 's jaars, te Dordrecht en te Middelburg;

$f 2.50$ 's jaars, te Amsterdam;

$f 2$ s jaars, te Utrecht;

$f 2$ tot $f$ a 's jars, to Gouda.

Te Deventer is het schoolgeld van 70 cents per uur 's weeks tot $f 6$ 's jaars. Aan de burgeravondschool te Leiden $f 10$ 's jaars, aan de ambachtsschool aldaar van $f 3$ tot $f 16$ 's jaars. Aan de Akademie van Beeldende Kunsten te Rotterdam wordt van $f$ 1,50 tot $f 5$ 's jaars voor het onderwije betaald. 
Te Delft en te Kampen wordt het onderwijs aan de burgeravondschool gratis gegeren.

Ten slotte nog een enkel woord over de Industrieschool voor vrouwelijke jeugd te Amsterdam, waarop ik ook reeds in mijn vorig opstel de aandacht vestigde. De nieuwe regeling, waarvan daar sprake was, is in Mei 1868 in werking gekomen, op welk tijdstip de nieuw benoemde drrectrice hare functiën heeft aanvaard. Het onderwijzend personeel bestond in December 1868 uit de directrice, vijf onderwijzeressen, belast met het onderwijs in fraaije en nuttige handwerken, teekenen en kleuren, benevens zes onderwijzers, van welke een onderwijs geeft in wis- en natuurkundige wetenschappen en herhaling van het lager onderwijs, een in boekhouden, een in teekenen, een in stroovlechten, een in kartonneeren en een in pharmacie. Dit laatste vak is eerst onlangs onder de leervakken opgenomen; de mersjes vinden er nu gelegenherd om die kundigheden op te doen, die rereischt worden bij het examen als apothekers-leerlng; een afzonderlijk vertrek is bepaald voor dit onderwijs ingericht. De kosten van het onderwijzend personeel bedragen ongeveer $f 5700$ 's jaars. De school geniet een Rijkssubsidie van $f 3000$ 's jaars en eene toelage van de gemeente van $f 1500$; bovendien heeft de provincle Noordholland over 1868 een subsidie van $f 3000$ in eens toegestaan. De kosten worden verder bestreden door eene toelage van de Maatschappij tot Nut van 't Algemeen, die deze innchting tot stand bracht, de contributiën van eenige particulieren en de thans rrij aanzienlijke opbrengst van de schoolgelden. Flke leerling betaalt $f 25$ of $f 20$ 's jaars; haar getal bedroeg in December 1868 reeds 105. Van dezen waren er 35 in de laagste, 46 in de tweede en 24 in de hoogste klasse; naar den leeftijd waren er 7 meisjes beneden 12 jaren, 34 van 12-14 jaren, 38 van $14-16$ jaren, 23 van $16-18$ jaren en 3 boven 18 jaren. Ten einde men nog beter kunne oordeelen over de maatschappelijke positie der meisjes, die van deze school gebruik maken, laat $\mathrm{lk}$ hier eene volledige opgave volgen van het beroep of de betrekking, waarin hare ouders werkzaam zijn.

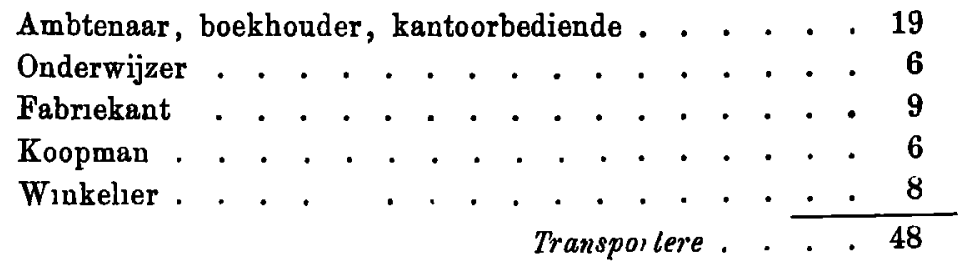




\begin{tabular}{|c|c|c|c|c|c|c|c|c|c|c|c|}
\hline & & & & & $\operatorname{Tra}$ & $2 s p$ & & & & & . 48 \\
\hline Apotheker. . . . & & & & . & . & . & $\cdot$ & • & . & • & 2 \\
\hline Stuurman . . . . & . & - & . . & . & . & . & $\cdot$ & - & . & • & 2 \\
\hline Diamantslijper & & & & . & - & $\cdot$ & - & - & . & • & 4 \\
\hline Goudsmid, horlogiemaker & & 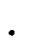 & & & . & - & - & - & . & . & 6 \\
\hline Schoen- of kleermaker & & 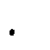 & & & . & - & $\cdot$ & - & . & . & 4 \\
\hline Bakker . . . . . . & • & - & . & . . & . & . & . & - & . & • & 3 \\
\hline Koetsier . . . . . & - & - & . & · . & . & - & - & . & . & $\cdot$ & 4 \\
\hline . . . . . & . & - & & . & - & . & . & • & - & • & 3 \\
\hline Andere ambachten & $\cdot$ & & & - & - & & • & - & - & & 6 \\
\hline Zonder beroep . . . & ${ }^{\circ}$ & & & . & . & • & - & • & . & • & $\mathbf{7}$ \\
\hline Overleden & & - & & & - & - & $\cdot$ & • & . & & . 16 \\
\hline
\end{tabular}

Na verloop van eenige jaren zal het belangrijk zijn eens na te gaan, op welke wijze de leorlungen na het verlaten der school van de daar opgedane kundigheden hebben kunnen partij trekken.

KOSTEN VAN HET MIDDELBAAR ONDERWIJS.

In het Regeeringsverslag van den staat der hoogere, middelbare en lagere scholen over 1866/67 komt eene opgave voor van hetgeen in 1866 door het Rijk en de gemeenten ten behoeve van het middelbaar onderwijs is uitgegeven. Ik laat hier een uittreksel daarvan volgen, op dezelfde wijze ingericht als de in mijn vorig opstel over de jaren 1863-1865 gegevene; in enkele onderdeelen is het nog eenigazins vollediger gemaakt.

De volgende tabel wijst de urgaven aan, in 1866 door het Rijk gedaan, alsmede de opbrengst van schoolgelden aan de Rijks-1nrichtingen en van examen-gelden. 


\begin{tabular}{|c|c|c|c|c|c|c|c|}
\hline \multirow{2}{*}{$\begin{array}{c}\text { GEMEENTEN } \\
\text { EN } \\
\text { ON UERWERPEN. }\end{array}$} & \multicolumn{3}{|c|}{$\begin{array}{l}\text { UITGAVEN VAN HET RIJK VOOR } \\
\text { RIJKS HOOGERE BURGERSCHOLEN }\end{array}$} & \multirow{2}{*}{ 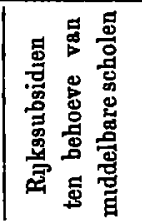 } & \multirow{2}{*}{ 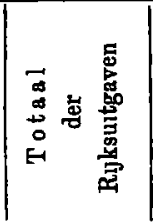 } & \multirow{2}{*}{ 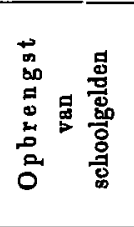 } & \multirow{2}{*}{ 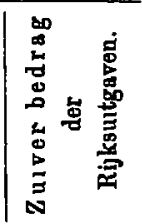 } \\
\hline & Personeel & Materieel & Totaal & & & & \\
\hline lburg & $1873360^{5}$ & $2351134^{5}$ & 4224495 & " & 4224495 & 45600 & 4178895 \\
\hline rnhem & " & $"$ & $"$ & 201630 & 201630 & " & 201630 \\
\hline ymegen & " & " & $"$ & 500000 & 500000 & $"$ & 500000 \\
\hline tphen & " & $"$ & $"$ & 700000 & 700000 & $"$ & 700000 \\
\hline tterdam & " & $"$ & " & 700000 & 700000 & $"$ & 700000 \\
\hline Iden & " & $"$ & $"$ & 700000 & 700000 & $"$ & 700000 \\
\hline rdrecht & " & $"$ & , & 700000 & 700000 & $"$ & 700000 \\
\hline elft & $"$ & $*$ & $"$ & 700000 & 700000 & $"$ & 7000.00 \\
\hline onda & $1181666^{5}$ & 453268 & $1634934^{5}$ & $"$ & $1634934^{5}$ & 72000 & $1562934^{5}$ \\
\hline Laarlem & $"$ & $"$ & $"$ & 700000 & 700 & $"$ & 7000.00 \\
\hline aan & $"$ & $"$ & $"$ & 375000 & 375 & $"$ & 3750.00 \\
\hline IIddelburg & 2098333 & 551859 & 2650192 & " & 2650 & 267684 & 2382508 \\
\hline Yoes & " & $"$ & $"$ & 700000 & 700 & $"$ & 7000.00 \\
\hline Jtrecht & 891714 & $79042.80^{5}$ & $8795924^{5}$ & $"$ & $8795994^{3}$ & 1030.00 & $8692994^{5}$ \\
\hline eden & $"$ & 1223479 & 1223479 & $"$ & 1223 & $"$ & 1223479 \\
\hline b s & " & $"$ & " & 500000 & 500 & $"$ & 5000.00 \\
\hline id & $"$ & $"$ & " & 50000 & 50 & . & 500.00 \\
\hline leek & " & $"$ & $"$ & 700000 & 700 & " & 7000.00 \\
\hline & “ & 。 & " & 700000 & 700 & $"$ & 700000 \\
\hline de & " & $"$ & $"$ & 700000 & 700 & $"$ & 700000 \\
\hline 8 & 20074.995 & $470156^{5}$ & 2477656 & ॥ & 2477 & 3670.00 & 21106.56 \\
\hline & " & $"$ & & 600000 & 600 & " & 600000 \\
\hline $\mathrm{am}$ & . & " & $"$ & 166666 & 166 & " & 166666 \\
\hline & " & " & " & 1000000 & 1000000 & “ & 1000000 \\
\hline Lee & 2132429 & $1767242^{5}$ & $39066.71^{5}$ & " & $39066.71^{5}$ & 143375 & $3763296^{5}$ \\
\hline Venlo & 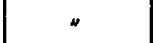 & $"$ & $"$ & 375000 & 3750.00 & $"$ & 3750.00 \\
\hline Totaal ... & $10192002^{5}$ & 147214,20 & $24913422^{5}$ & 10768296 & $356817.18^{5}$ & 998659 & 346830595 \\
\hline $\begin{array}{l}\text { Uitgaven van } \\
\text { verschallenden }\end{array}$ & & & & & & & \\
\hline $\begin{array}{r}\text { aard } \\
\text { nspecteurs }\end{array}$ & & " & 11199.15 & 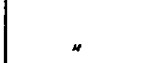 & 1119915 & " & 11199.15 \\
\hline Examens & 12663.41 & " & 1266341 & $"$ & 1266341 & 47479 & 12188.62 \\
\hline Polyt School & $6698191^{5}$ & $2890413^{5}$ & 9588605 & $"$ & 9588605 & 2551000 & 70376.05 \\
\hline $\begin{array}{l}\text { Algem uitgaven } \\
\text { voor de h. b. s. }\end{array}$ & " & 351258 & 351258 & " & & & \\
\hline $\begin{array}{l}\text { Totaal .... } \\
\text { Alg totaal. }\end{array}$ & 90844475 & $3241671^{5}$ & 12326119 & ״ & 9 & 2598479 & 9727 \\
\hline Alg totaal. & 601 & & & 10768296 & 75 & & $444106.99^{5}$ \\
\hline De in de & , & & & & & & \\
\hline
\end{tabular}




\begin{tabular}{|c|c|c|c|c|c|c|c|}
\hline \multirow{3}{*}{ GEMEENTEN } & \multicolumn{7}{|c|}{ UITGAVEN. } \\
\hline & \multicolumn{3}{|c|}{ HOOGERE BURGERSCHOLEN } & \multicolumn{3}{|c|}{ BURGERSCHOLEN. } & \multirow{2}{*}{$\begin{array}{c}\text { Commiss } \\
\text { van } \\
\text { toeznd }\end{array}$} \\
\hline & Personeel & Materieel & Totaal & Personeel. & Materneel & Totanl. & \\
\hline s Hertogenb. & 》 & ఎ & 》 & $"$ & " & 》 & $y$ \\
\hline Helmond & D & D & 》 & ” & v & » & , \\
\hline Arnhem & 779563 & $9330874^{5}$ & $101104.37^{5}$ & 》 & 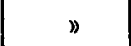 & ఐ & 2000 \\
\hline Niymegen & 832500 & 206536 & 1039036 & 412500 & » & 4125.00 & 2000 \\
\hline Zutphen & 1071498 & 3369.46 & 1408444 & 552665 & $n$ & 5526.65 & 750 \\
\hline 's Gravenhage & 25277.76 & 1148.12 & 2642588 & $964.70^{5}$ & 21340 & $1178.10^{5}$ & 1200 \\
\hline Rotterdam & 26365.00 & 396110 & 3032610 & 》 & v & 》 & 337. \\
\hline Leiden & 1182900 & $191609^{5}$ & $1374509^{5}$ & 》) & D & $\nu$ & 50 \\
\hline Dordrecht & 1800800 & $438073^{5}$ & $22388.73^{5}$ & 56665 & $180.80^{5}$ & $747.45^{5}$ & 1000 \\
\hline Delft & 17183.30 & $3538.54^{5}$ & $2072184^{5}$ & 335188 & $96674^{5}$ & $4318.62^{5}$ & 75 \\
\hline Gouda & » & 》 & ఐ & 1328.32 & $506.31^{5}$ & $183463^{5}$ & 500 \\
\hline Amsterdam & 26950.00 & $2959.17^{3}$ & $2990917^{5}$ & p & 》) & v & 135.! \\
\hline Haarlem & 1611600 & $343505^{5}$ & $19551.05^{5}$ & 3418.92 & 927.03 & 434595 & , \\
\hline Zaandam & 672500 & 427421 & 1099921 & 1125.00 & 142.70 & 1267.70 & 2000. \\
\hline Alkmaar & $n$ & ” & $\smile \cdots$ & $"$ & ” & 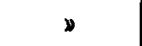 & I \\
\hline Goes & 9691.66 & 217811 & 1186977 & 20000 & 4470 & 244.70 & 50.0 \\
\hline Utrecht & D &  & n & 1435 & $"$ & 14.35 & 750 \\
\hline Leeuwarden & $"$ & 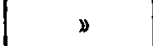 & $n$ & ע & » & $n$ & , \\
\hline Harlıngen & 8700.00 & $2389.91^{5}$ & $11089.91^{5}$ & 160000 & 》 & 1600.00 & 150 \\
\hline Sneek & 14492.44 & $273076^{5}$ & $1722320^{5}$ & 600.00 & D & 60000 & 800 \\
\hline Zwolle & D & 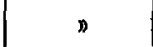 & $»$ & 》 & $»$ & $»$ & 1001 \\
\hline Deventer & 19245.43 & 429525 & 2354068 & 3536.38 & 561.18 & 4097.56 & 1101 \\
\hline Enschede & v & $n$ & D & D & $"$ & 》 & , \\
\hline Groningen & $"$ & $n$ & 》 & $237249^{5}$ & 799.67 & $3172.16^{5}$ & 1001 \\
\hline Veendam & 318000 & 12148.23 & 1532823 &  & $n$ & 》) & 1001 \\
\hline Maastricht & 1949873 & $1623.23^{5}$ & $2112196^{5}$ & D & » & 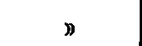 & 28.5 \\
\hline Venlo & 326666 & $2336.10^{5}$ & $560276^{5}$ & " & " & " & , \\
\hline Totaal & 253364.59 & 15205821 & 40542280 & 2873035 & $4342.54^{5}$ & $3307289^{5}$ & 22011 \\
\hline
\end{tabular}


463

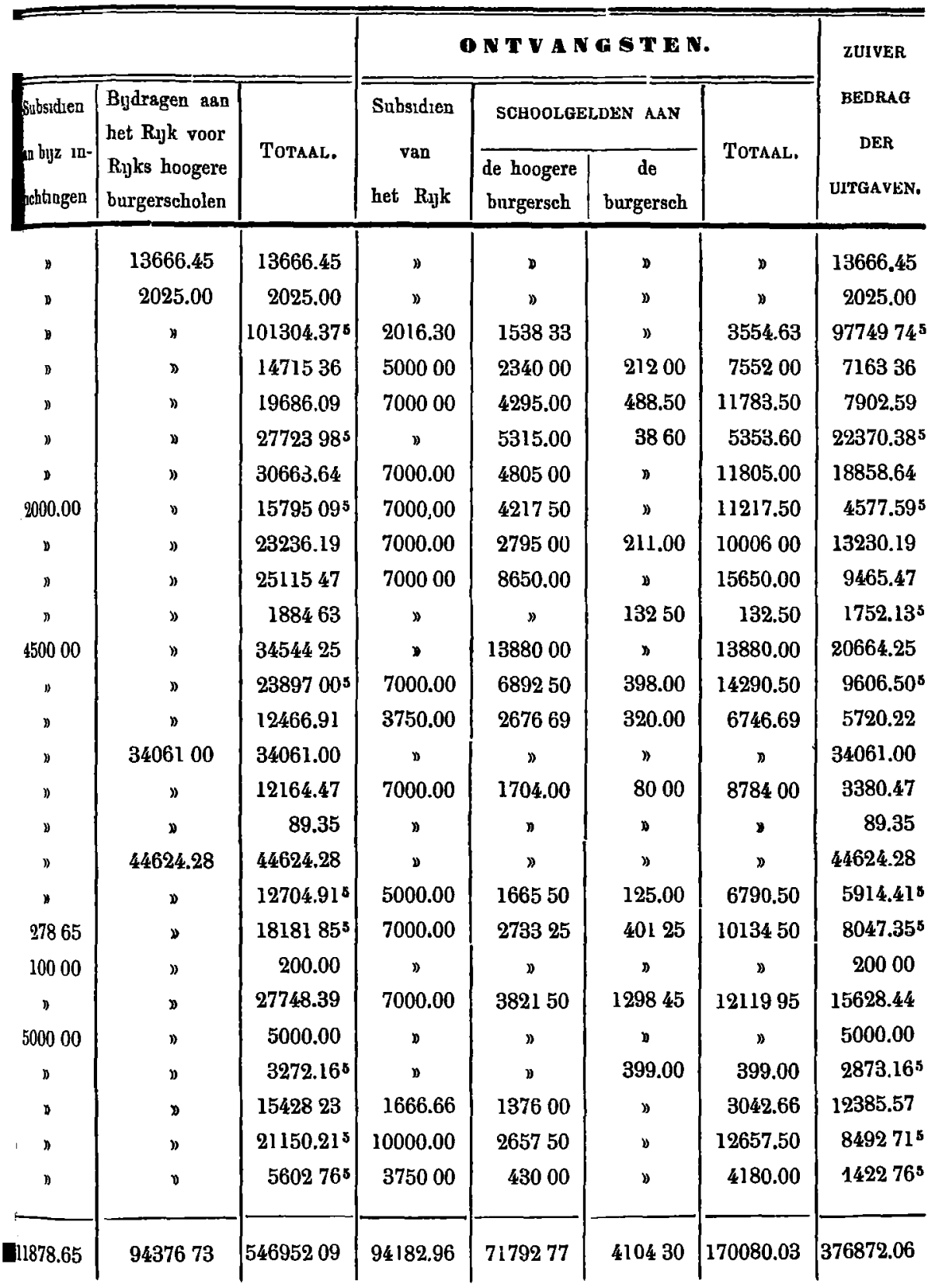


Ik heb deze opgaven onveranderd overgenomen; in het Regeeringsverslag wordt te vergeefs eenige toelichting gezocht Voor sommige gemeenten zijn buiten twijfel de kosten der hoogere burgerschool en de der burgeravondschool niet volkomen uit een gehouden; het laat zich anders niet verklaren, hoe aan enkele dezer laatsten volstrekt geen uitgaven voor materieel zouden hebben plaats gehad. De aanzienlijke uitgaven der gemeenten Arnhem en Veendam voor materieel zullen wel aan het bouwen van nieuwe localen zijn toe te schrijven. Het subsidie van $f 2000$ te Leiden werd gegeven aan de bijzondere burgeravondschool; de $f 4500$ te Amsterdam waren, naar Ik meen, bestemd voor de ambachtschool van de Maatschappij van den Werkenden Stand en voor het zoogenaamde Volksonderwijs, gegeven van wege de Maatschappij tot Nut van 't Algemeen. Wat de gemeente Sneek betreft, weet ik evenmin de kosten $\operatorname{van} f 600$ voor personeel der burgerschool en de schoolgelden ten bedrage van $f 401.25$ voor die inrichting, van wier bestaan mij niets bekend is en ook uit het Regeeringsverslag niets blijkt, als het subsidie van $f 278.65$ te verklaren; hetzelfde geldt van het achter $Z_{\text {wolle }}$ utgetrokken subsidie van $f 100$. Het subsidie van $f 5000$, bij Enschede vermeld, werd door de gemeente aan de daar bestaande hoogere burgerschool (School voor Handel en Nijverheid) gegeven. De vier sommen, achter de namen der gemeenten 's Hertogenbosch, Helmond, Alkmaar en Leeuwarden in de 10 e kolom uitgetrokken, zijn de geheele of gedeeltelijke kosten der gebouwen, door de gemeente ten behoeve der Rukssehool gesticht. Hot totaal der subsidiën van het Rijk bedraagt in deze tabel $f 1350000$ meer dan in die der Rijksuitgaven, omdat in laatstgenoemde bovendien voorkomen de subsidiën, door het Rijk toegekend aan de school te Enschede, de landbouwschool te Groningen en de zeevaartschool te Harlingen.

In het volgend tabellariesch overzıcht heb $1 \mathrm{k}$ alle uitgaven, die in 1866 door het Rijk en de gemeenten ten behoeve van het middelbaar onderwije zijn gedaan, alsmede de opbrengst der schoolgelden opgenomen. 


\begin{tabular}{|c|c|c|c|c|}
\hline $\begin{array}{c}\text { GEME ENTEN } \\
\text { EN } \\
\text { ONUERWERPEN. }\end{array}$ & $\begin{array}{c}\text { BEDRAG } \\
\text { der untgaven } \\
\text { van het Ryjk }\end{array}$ & $\begin{array}{c}\text { BEDRAG } \\
\text { der utgaven } \\
\text { van de } \\
\text { gemeenten }\end{array}$ & $\begin{array}{l}\text { OPBRENGST } \\
\text { van school- en } \\
\text { examengelden }\end{array}$ & $\begin{array}{l}\text { TOTAAL } \\
\text { der } \\
\text { KOSTEN. }\end{array}$ \\
\hline $\begin{array}{l}\text { 's Hertogenbosch } \\
\text { Tilburg } \\
\text { Helmond } \\
\text { Arnhem } \\
\text { Nymegen } \\
\text { Zutphen } \\
\text { 's Gravenhage } \\
\text { Rotterdam } \\
\text { Leiden } \\
\text { Dordrecht } \\
\text { Delft } \\
\text { Gouda } \\
\text { Amsterdam } \\
\text { Haarlem } \\
\text { Zaandam } \\
\text { Alkmaar } \\
\text { Middelburg } \\
\text { Goes } \\
\text { Utrecht } \\
\text { Leeuwarden } \\
\text { Harlingen } \\
\text { id (zeevaartsch) } \\
\text { Sneek } \\
\text { Zwolle } \\
\text { Deventer } \\
\text { Enschede } \\
\text { Groningen } \\
\text { id. (landb school) } \\
\text { Veendarn } \\
\text { Maastncht } \\
\text { Roermond } \\
\text { Venlo } \\
\text { Inspecteurs } \\
\text { Exameng } \\
\text { Polytechn. School } \\
\text { Algemeene uitgaven }\end{array}$ & $\begin{array}{c}\text { f } 417895 \\
\prime \prime \\
201630 \\
500000 \\
700000 \\
\prime \prime \\
700000 \\
700000 \\
700000 \\
700000 \\
15629345 \\
\prime \prime \\
700000 \\
375000 \\
\prime \prime \\
2382508 \\
7000.00 \\
86929945 \\
1223479 \\
500000 \\
50000 \\
700000 \\
" \prime \\
700000 \\
700000 \\
2110656 \\
600000 \\
166666 \\
1000000 \\
3763296^{5} \\
375000 \\
1119915 \\
1218862 \\
7037605 \\
351258\end{array}$ & 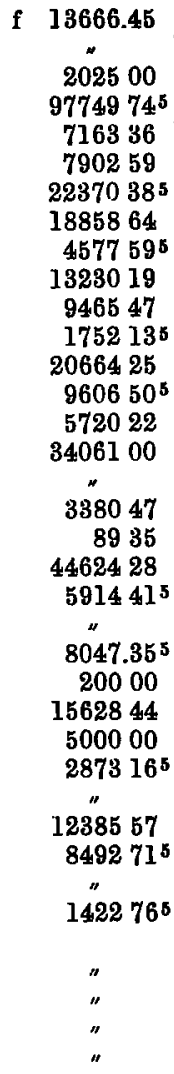 & $\begin{array}{c}" 4600 \\
4 \quad \\
153833 \\
255200 \\
478350 \\
5353.60 \\
480500 \\
421750 \\
300600 \\
8650.00 \\
85250 \\
13880.00 \\
729050 \\
299669 \\
" \\
267684 \\
178400 \\
103000 \\
" \prime \\
179050 \\
" \prime \\
313450 \\
" \\
511995 \\
4 \\
406900 \\
1376.00 \\
265750 \\
143375 \\
43000 \\
474.79 \\
2551000 \\
" \\
\end{array}$ & $\begin{array}{c}1366645 \\
4224495 \\
202500 \\
101304.37^{5} \\
1471536 \\
19686.09 \\
2772398^{5} \\
3066364 \\
15795095 \\
2323619 \\
2511547 \\
1823398 \\
3454425 \\
2389700^{5} \\
1246691 \\
3406100 \\
2650192 \\
1216447 \\
88049295 \\
56859.07 \\
1270491^{5} \\
50000 \\
18181.855 \\
20000 \\
27748.39 \\
1200000 \\
28048725 \\
600000 \\
1542823 \\
21150215 \\
39066715 \\
560276^{5}\end{array}$ \\
\hline $\begin{array}{l}\text { Totaal } \\
\text { Idem in } 1865\end{array}$ & f $\begin{array}{r}44410 \\
30757\end{array}$ & f $\begin{array}{r}37687206 \\
57567914\end{array}$ & f 111868 & 9528 \\
\hline
\end{tabular}

De kosten van de school te Enschede, de landbouwschool te Gronıngen, de zeevaartschool te Harlingen en de andere bijzondere scholen zijn in deze tabel niet opgenomen dan voor zooveel de door het Rijk en de gemeenten toegekende subsidjën betreft; ook de daarvoor opgebrachte schoolgelden komen in het Regeeringsverslag niet voor. Strikt genomen zouden dus de totalen in de drie laatste 
kolommen der voorgaande tabel eene kleine verhooging moeten ondergaan.

Vergelijkt men de totalen voor 1866 met die voor 1865 , welke ik daaronder heb geplaatst, dan ziet men, dat het totaal bedrag der uitgaven in $1866 f 19959.83^{5}$ minder is geweest. De urtgaven van het Rijk zijn toegenomen met $f 136529.10^{5}$, de opbrengst der schoolgelden met $f$ 42318.14, terwijl de uitgaven der gemeenten in 1866 $f 198807.08$ minder bedroegen dan in 1865 . Deze laatste vermindernng is echter daaraan toe te schrijven, dat minder voor stichting van gebouwen en voor aankoop van hulpmiddelen behoefde te worden uitgegeven.

Ik zal niet noodig hebben her nog in bjjzonderheden an to toonen, dat ook voor 1866 de uitgaven nog niet in een normalen toestand verkeerden; mijns inziens kan dit voor het Rijk en de meeste gemeenten eerst in 1870 of 1871 het geval zijn.

's Graven hage, Februarij 1869.

Steyn Parvé.

Verbeteringen In de tabel op ble 354, 4e kolom, achter Roermond, staat 11, lees. ", als totaal van die kolom staat 25 , lees. 14 .

$O p$ blz 360, r 15 v b staat $f 41320$, lees. $f 41820$. 